\title{
Genesi di una forma tra idea, geometria e materia. Francesco Berarducci. Analisi della Chiesa di San Valentino al Villaggio Olimpico
}

\author{
Luca Ribichini \\ Lorenzo Tarquini \\ Mario Ciamba \\ Ivan Valcerca \\ Massimiliano Mastracci
}

Abstract

II complesso parrocchiale di S. Valentino si trova all' interno del Villaggio Olimpico a Roma. Gli edifici nati per ospitare gli atleti partecipanti ai Giochi Olimpici di Roma del 1960 si trasformeranno successivamente in un vero e proprio quartiere.

Nel 1979 l'architetto Francesco Berarducci fu incaricato della realizzazione del progetto dell'attuale chiesa. Tramite i suoi disegni ideali e utopici possiamo cercare di comprendere al meglio la sua visione del mondo e della sua architettura. Tramite questi piccoli pezzi di carta, a volte stropicciati e rovinati ritroviamo la filosofia di intervento e i valori fondanti della propria ricerca. Possiamo dire senza enfasi che questi schizzi rappresentano la vera essenza del pensiero di Berarducci nei confronti del tema della chiesa. Al centro della propria riflessione Berarducci auspicava e affermava la necessità del ritorno ad un linguaggio formale più lineare e pacato che mettesse in risalto la serenità spirituale dell'edificio ecclesiastico. II modello di riferimento è l'architettura romana.

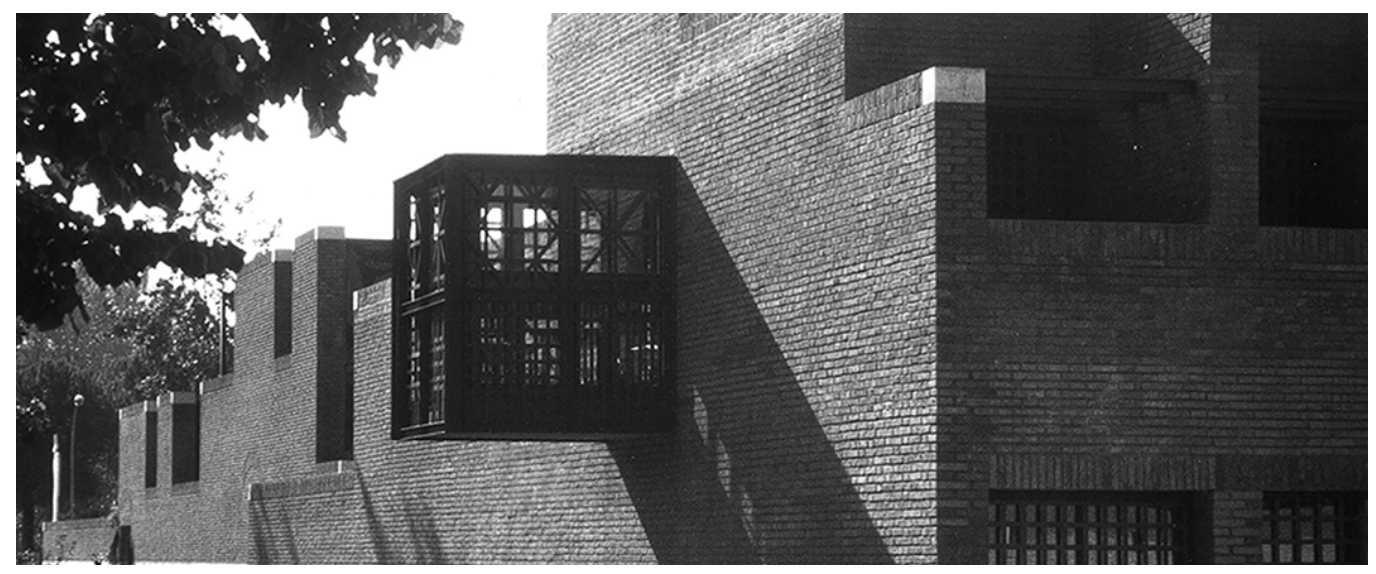




\section{Introduzione}

Per arrivare a disegnare un edificio, o uno spazio architettonico si parte da un'idea primigenia o da uno studio che spesso è scaturito da una serie di schizzi e di disegni preparatori, che hanno l'indubbio merito di mettere a fuoco le intenzioni dell'architetto.

Ricordiamo per esempio Palladio, il quale su un tema specifico, sviluppava diverse ipotesi generative utilizzando una metodica di investigare una serie di varianti possibili sul tema dato, fino ad avere una quantità considerevole di possibili soluzioni (fig. I).

A volte molti architetti, non hanno elaborato nessun tipo di percorso, o non hanno sviluppato un vero e proprio metodo personale per arrivare a definire la 'forma'.

Altri invece hanno adottato una strategia che emerge ed è evidente, di mettere a punto e di praticare una metodologia spesso rigorosa, soprattutto nei loro schizzi, nei loro disegni sia preparatori che definitivi, basta avere la pazienza di riuscire a 'vedere' e a leggere dentro i disegni di progetto.

Decisiva, come sempre, è la funzione dell'osservare, che come in tutte le discipline, si sostanzia nella paziente e costante analisi, dove la sensibilità, l'attenzione e la precisione dell'osservatore umano, riesce a far emergere nuove interpretazioni. A volte basta un particolare, o ricavare informazioni con una nuova visione d'insieme, o cogliere un dettaglio significativo, che si aprono nuovi scenari interpretativi e ci introducono a nuove verità.

Questo è il caso di Francesco Berarducci [ I ] nella chiesa di San Valentino al Villaggio Olimpico a Roma, dove ci è sembrato di comprendere la genesi creativa dell'opera realizzata grazie ad un attento studio dei suoi elaborati di disegno e attraverso i suoi scritti.

L'operazione di cercare di individuare le linee immaginifiche e procedurali all'inizio del processo creativo non è un'impresa sterile e fine a se stessa, ma ha l'ambizione di poter far luce

sul 'come' e sul 'perché' un architetto arriva ad una definizione ben precisa di una architettura.

Fig. I. Andrea Palladio. Diverse soluzioni planimetriche per un edificio forse Palazzo Volpe a Vicenza (da: R. de Rubertis, II disegno dell'architettura, Roma, 2002, pag I58).

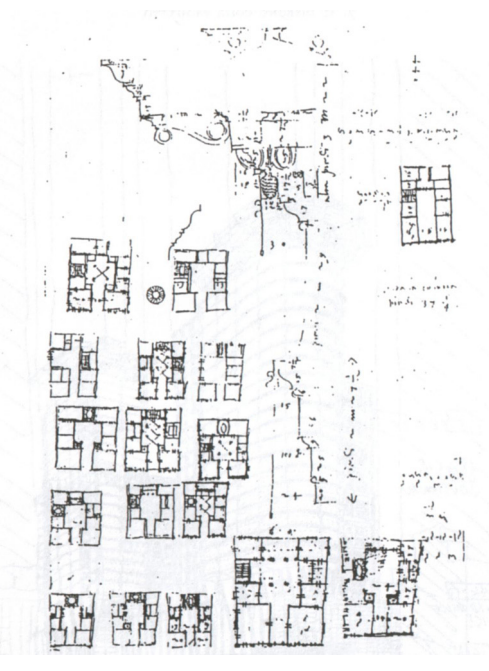

\section{Metodologia francese}

La metodologia che usa un approccio 'genetico' per studiare la fase aurorale di un componimento creativo nasce in Francia, ma ha un'origine principalmente nel campo letterario, infatti grazie al ritrovamento di alcuni manoscritti di alcuni poeti e scrittori francesi, si sono ritrovate le modifiche, i pentimenti, i cambiamenti, di autori quali Hugo,Verlaine, Baudelaire. Studiando queste carte si sono rintracciate l'evoluzioni creatrici dell'opere fino alla redazione e stesura finale.

Proprio da questi fogli, abbiamo una conoscenza più profonda delle motivazioni dei vari autori. Allo stesso modo facendo un parallelo con l'architettura, tra fogli stropicciati dei 
Fig. 2. Studio Berarducci, disegno teorico di città, si osservi la maglia costruttiva schizzata in basso al $d$ isegno che definisce il concetto di modulo di griglia.

Fig. 3. Studio Berarducci, schizzo di studio per città ipotesi di struttura frantumata, si osservi la maglia generativa che ha come modulo di riferimento il cubo. primi schizzi, dei primi disegni, delle note a lato degli sketch si ritrovano le intenzionalità, le metodologie, che purtroppo il più delle volte, questi pezzi di carta, spesso vengono cestinati, o al più terminato il progetto, vengono relegati in qualche cassetto polveroso. Con questo spirito abbiamo cercato di rivedere i disegni preparatori per capire il componimento della chiesa di San Valentino al villaggio Olimpico alla stessa stregua di un'opera letteraria.
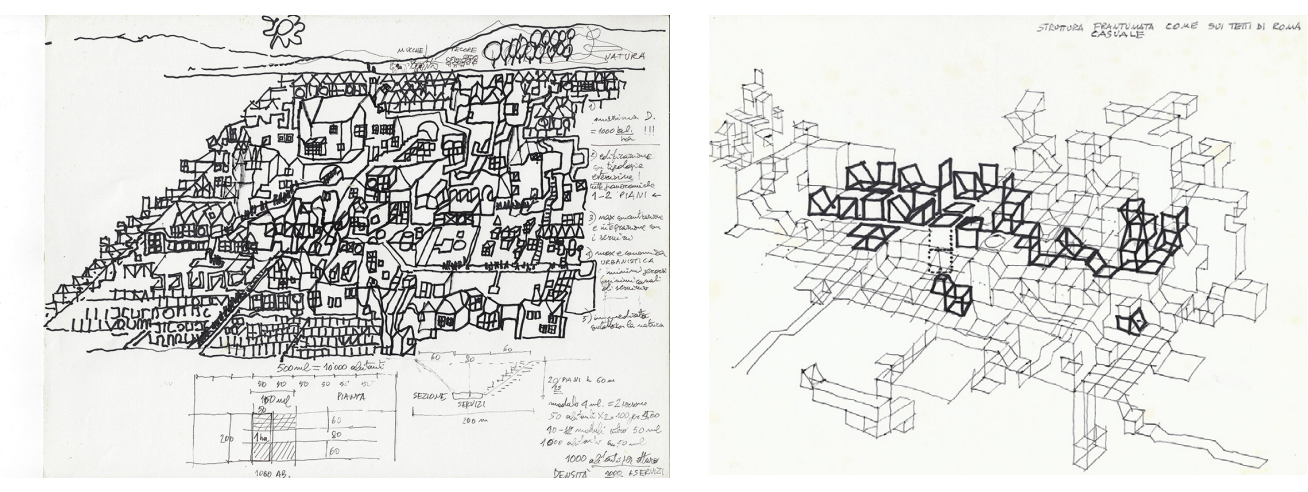

\section{La chiesa}

La chiesa di San Valentino al Villaggio Olimpico, progettata nel 1979 ed inaugurata nel 1987, è situata presso Viale XVII olimpiade (angolo via Germania) nel quartiere nato per gli atleti delle Olimpiadi del 1960 che prende il nome appunto di Villaggio Olimpico.

II contesto urbano si estende fra Villa Glori e la direttrice storica della via Flaminia, dove in questo frangente la parrocchia costituisce un blocco compatto e ben definito.A cavallo fra gli anni '70-'80 emergeva un'esigenza di rinnovare la qualità e l'identità delle chiese e dei complessi parrocchiali, promuovendo edifici che fossero attenti al "contesto ambientale, all'ospitalità liturgica, all'espressione artistica e alle esigenze pastorali più aggiornate" [Concilio Vaticano II].

L'indirizzo creativo era mirato ad un complesso in grado di creare una forte unione fra antico e contemporaneo, da una parte avere la potenza e il legame della tradizione e dell'eredità culturale, dall'altra la freschezza dell'innovazione in linea con i concetti architettonici più moderni.
Fig. 4. Studio Berarducci, schizzo di studio volumetrico per la chiesa d San Valentino al villaggio Olimpico, si osservi come la maglia generativa

e aggregativa faccia

riferimento al modulo quadrato o cubico.

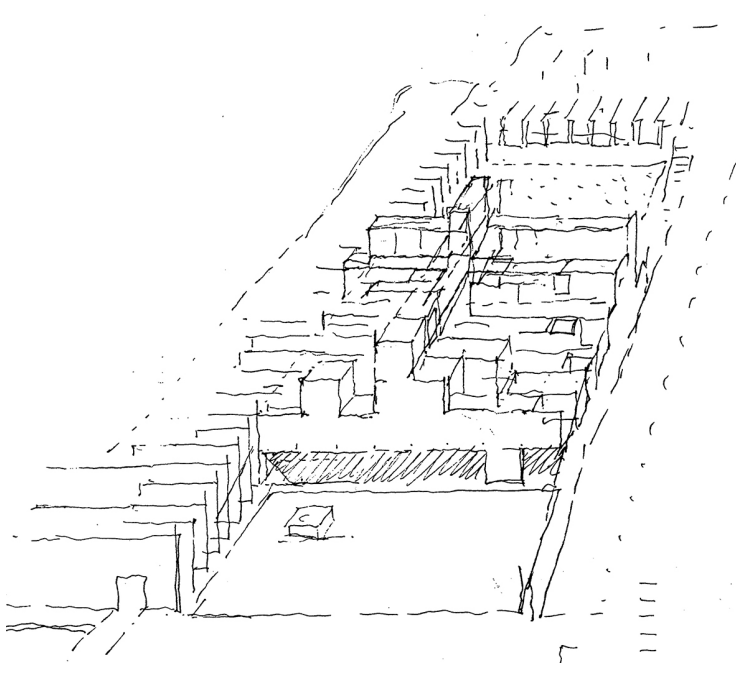


Per la realizzazione fu scelto Francesco Berarducci che, in risposta alle esigenze del contesto ecclesiale, aveva delineato tre scenari: II recupero del rapporto con la tradizione, l'adesione alle indicazioni liturgiche del Concilio Vaticano II, e in ultimo le soluzioni pragmatiche ed economiche, dettate dalle urgenze pastorali.

A ribadire la sua impostazione Berarducci parla così: "Dopo questa fase di ansiose ricerche sperimentali, ci si augura il ritorno a quella serenità spirituale, che genera sicurezza di intenti e pacatezza di linguaggio formale. Solo allora nuove e più rigorose figurazioni architettoniche potranno rievocare la profondità del messaggio culturale della millenaria tradizione ecclesiale" [Berarducci 1955] [2].
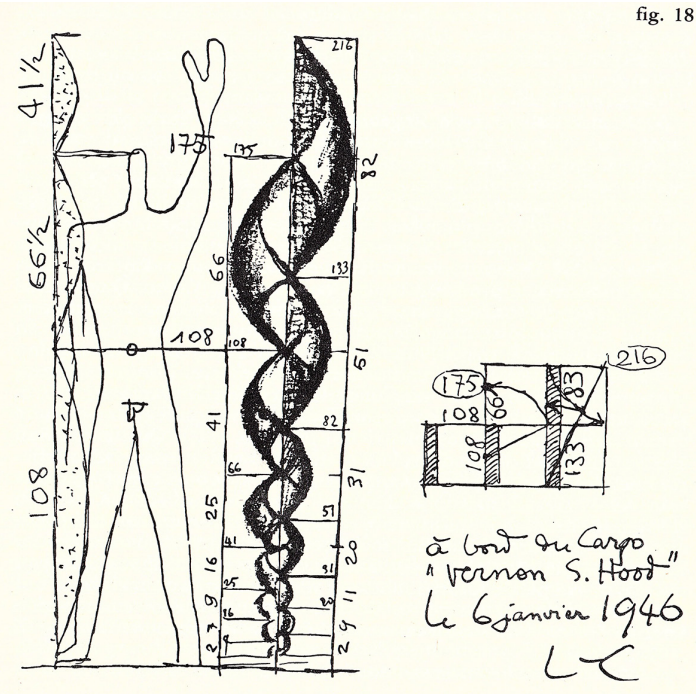

\section{Tra geometria e simbolo}

Il quadrato o meglio il cubo è alla base del componimento architettonico della chiesa, lo si evince da diversi disegni preparatori e dalla visione diretta della chiesa. Forse questa forma parte da lontano, probabilmente da un gruppo di disegni, di elaborati, di scritti che erano dedicati a una riflessione su un'idea di città lineare teorica, realizzati dal I979 al 1982 [3]. In questi disegni si teorizzava un tessuto abitativo che ha come ispirazione una serie di aggregazioni cubiche spontanee, che inevitabilmente ci evocano nella mente dei ricordi tipici delle città mediterranee (vedi Grecia, Amalfi, Positano, o altre città nel nord dell'africa (figg. 2, 3). L'idea di questa città teorica disegnata e immaginata in tutta la sua lunga esperienza lavorativa, si concretizza e prende forma nella chiesa di san Valentino dove Berarducci applica i suoi dettami teorici in un concreto esempio da realizzare e costruire.

Egli pone il quadrato come simbolo che esprime appartenenza e sacralità, raccoglimento nella sua forma contratta e definizione identitaria di essa, legato al principio terreno. II quadrato è la figura di base dello spazio, contrapposto al cerchio o alla spirale dove spesso si simboleggia il tempo, ma è anche il simbolo dell'universo creato in opposizione al caos al non creato. Ed ancora il cubo rappresenta nella amplissima letteratura, il simbolo della saggezza, della verità e della perfezione morale, ed è tra i tantissimi riferimenti il modello della Gerusalemme celeste evocata nell'Apocalisse nelle sue tre dimensioni uguali.

Dice Bruno Munari nel 1960 introducendo il quadrato nella sua monografia: "Il quadrato è la concentrazione estrema di un'idea spaziale in se stessa compiuta. Rappresenta un ordine di pregnante spirituale simbolismo. Tutti gli altri rettangoli, a lati diversi, si rifanno al quadrato come un allentamento della sua legge attraverso l'espansione in altezza o in larghezza" [Munari 1960]. 

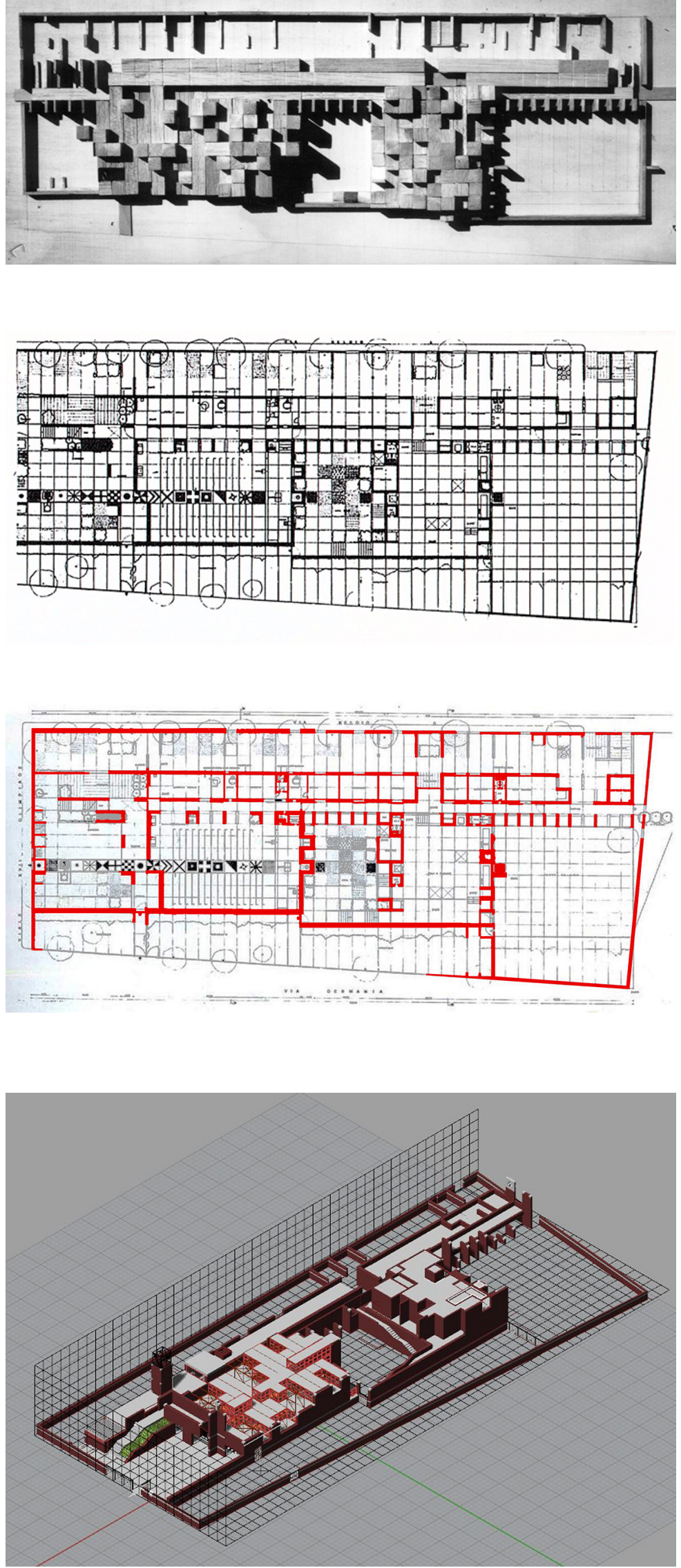
Fig. 10. Mies Van der Rohe, Casa modello per la mostra della Costruzione, Berlino 1931, pianta.
Fig. I I. Mies Van der Rohe, Padiglione all'Esposizione di Barcellona, 1929 pianta.

Fig. 12. Mies Van der Rohe, Padiglione all'Esposizione di Barcellona, 1929. diagramma.
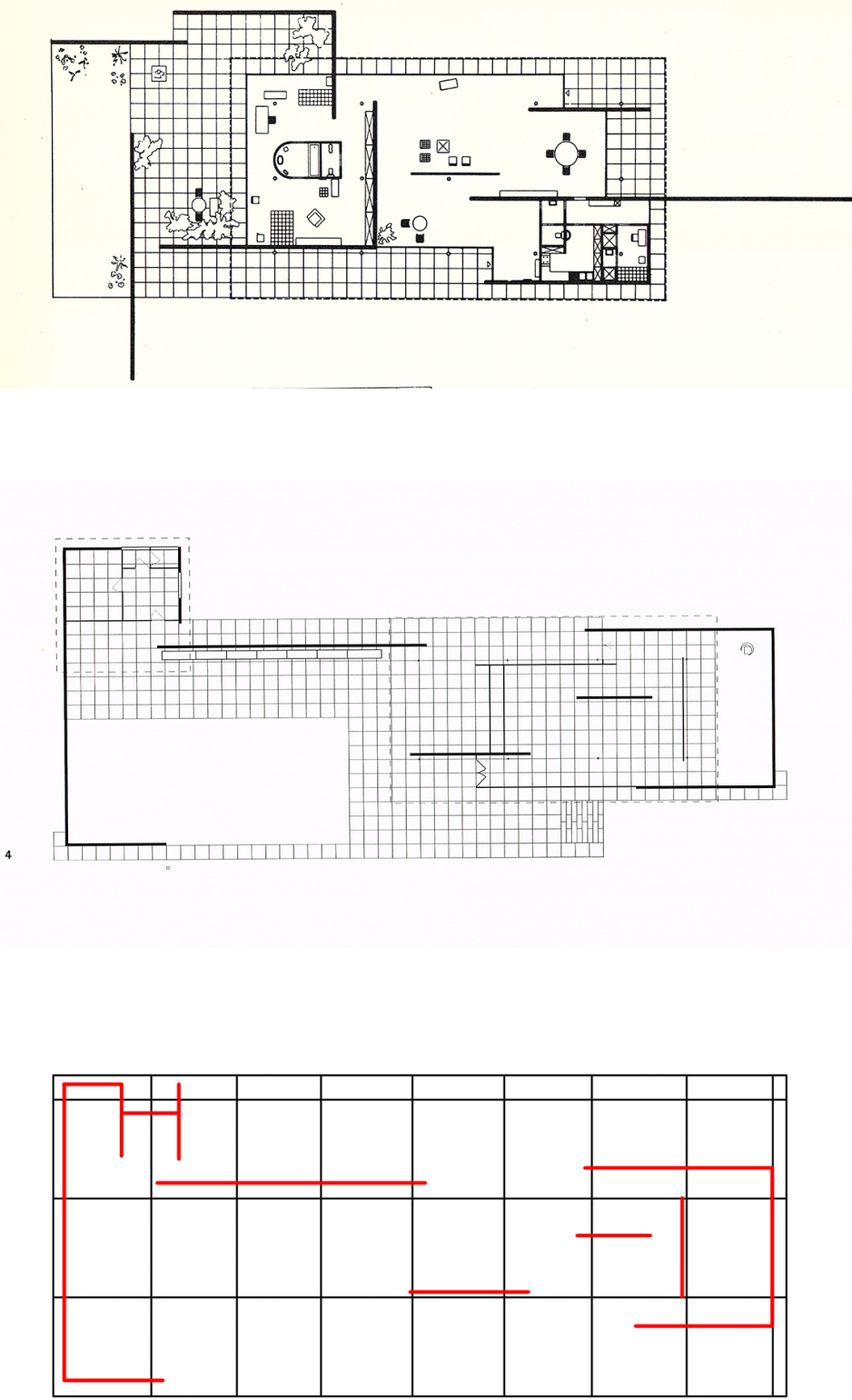

Dunque l'idea modulare che connota la conformazione spaziale, in pianta e in alzato della chiesa di S. Valentino al Villaggio Olimpico, trae origine da una ripartizione cartesiana di ascisse e ordinate che, intersecate fra di loro, generano la forma e lo spazio destinato alle funzioni ecclesiali diventando per sua natura sacro.

Berarducci imposta una griglia reticolare che ha come modulo generativo il quadrato che una volta descritto planimetricamente si sviluppa in altezza e nello spazio mantenendo le dimensioni e il ritmo compositivo, definendo il cubo come solido generatore.

II doppio rapporto, sia in pianta che in alzato è facilmente riconoscibile nel prospetto d'ingresso, dove il ritmo dei pieni e dei vuoti ne scandisce la facciata creando suggestivi giochi d'ombra geometricamente riconoscibili e coerenti (figg. 17, 18).

II valore metrico alla base del modulo è di 2,20 (metri) che suggerisce una particolare attenzione alla scala umana relazionando il risultato spaziale alla misura d'uomo, concetto che rimanda al Modulor di Le Corbusier e all'uomo vitruviano di Leonardo (fig. 5). 
Nella definizione della forma complessiva l'architetto qualifica lo spazio aggiungendo un ulteriore fattore connotativo che identifica e inserisce l'oggetto architettonico nel panorama culturale romano, mantenendo un legame espressivo forte con il contesto storico. Si avvale pertanto di una aggregazione che tende ad alterare la conformazione geometrica pura, definendo 'un'incompletezza' formale che rompe il vincolo temporale corruttore della materia, proiettando l'edificio in una sfera atemporale. Berarducci lascia pertanto immaginare, attraverso un processo mnemonico, la totale ricostruzione mentale, quasi fosse un incompiuto michelangiolesco che assurge ad uno spazio metafisico, reincarnando la sacralità delle rovine romane.

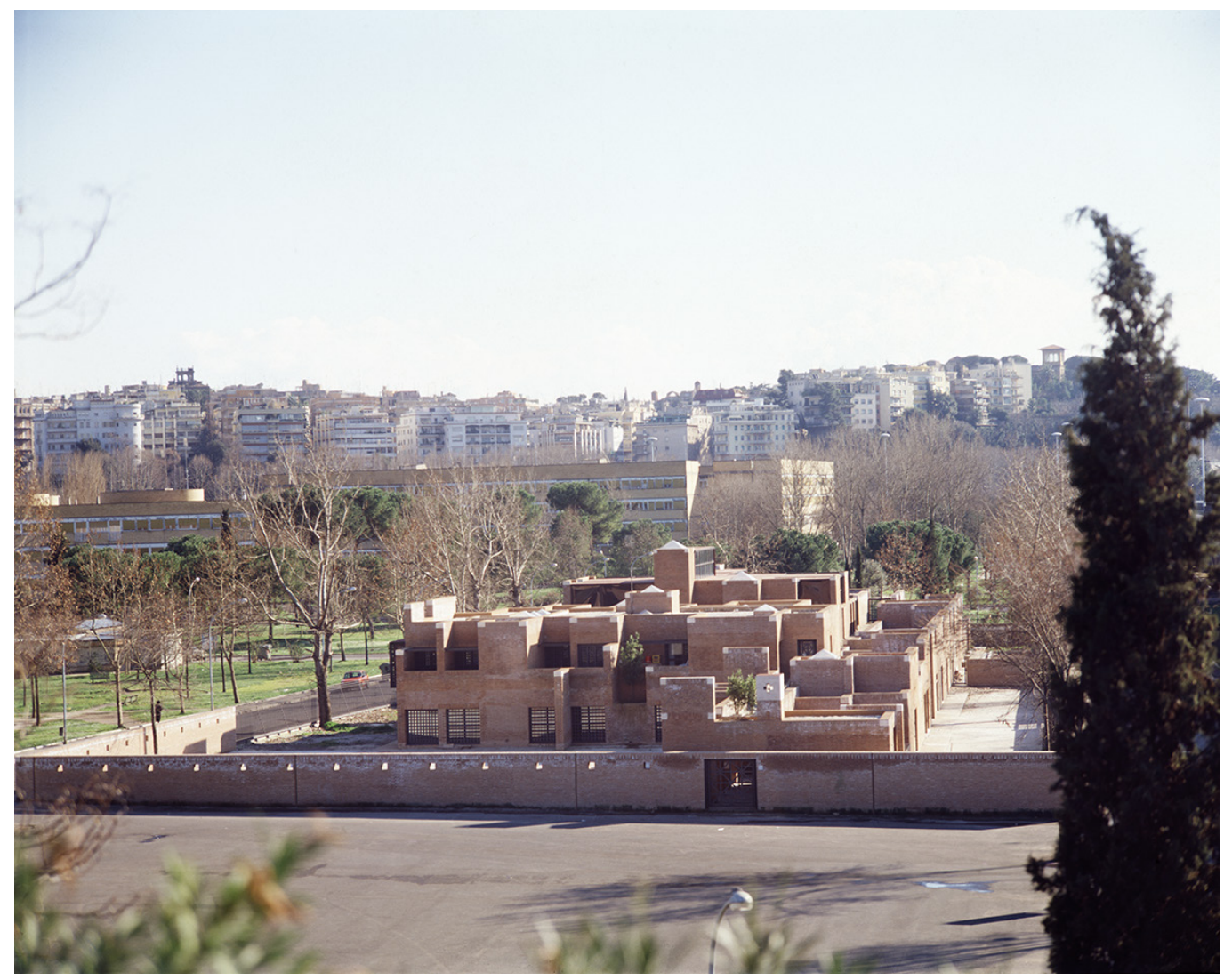

\section{Misura, modulo, parametro}

L'intero impianto planimetrico appare quindi generato mediante un modulo quadrato di lato 2,20, (metri) sia in pianta che in alzato (fig. 6,7).

Infatti osservando zenitalmente il complesso ecclesiastico si riconoscono chiaramente i diversi ambiti funzionali composti successivamente dalla corte d'ingresso, la chiesa, il cortile interno, la sagrestia, e i campi sportivi. Tutti questi spazi sono sovrapposti ad una maglia quadrata che si sviluppa sia longitudinalmente che trasversalmente creando una rete di moduli quadrati di dimensione 2,20 che come sopra descritto, programmano spazialmente e gerarchicamente tutta la superficie della parrocchia

Se tutto ciò è vero, emerge in modo evidente che San Valentino al villaggio Olimpico ha diverse analogie con i concetti generativi, spaziali, e di disegno con due grandi maestri; Mies van der Rohe [4], e Louis Khan.

Berarducci realizza l'edificio seguendo i dettami spaziali di Mies ma aggiungendo una variante fondamentale: pone l'attenzione alla presenza al luogo dove viene realizzata la sua opera. 
Fig. 14. II giardino come paradiso dove fiorisce la rosa, simbolicamente rappresenta l'eden, luogo preposto alla riflessione e alla meditazione dello spirito e dove l'anima si rigenera.
Qui Berarducci fa emergere la sua tradizione di architetto romano formatosi nella importante e prestigiosa scuola romana dove la memoria risulta essere decisiva per l'ideazione di ogni progetto.

In questo caso e' il 'genius loci' di Roma che si sostanzia 'in forma' nel concetto di rovina e di frammento. II richiamo a Louis Khan è inevitabile, il maestro americano suggerisce cosa deve essere un'architettura, e cosa deve essere un mattone. Berarducci non ha nessun dubbio, la presenza della Roma antica si deve sostanziare in quelle mura realizzate a mattoni.

Ovviamente la griglia 'generativa' oltre che a coprire completamente tutto il lotto, ne determina anche il confine della parrocchia. Infatti i muri perimetrali ad ovest (Via Belgio) ed a sud (via della XVII Olimpiade) seguono perpendicolarmente lo schema della maglia, mentre per i lati nord (via Irlanda) ed est (via Germania) i setti si orientano inevitabilmente allineandosi ai tracciati precedenti delle rispettive strade di adiacenza (fig. |3).

I muri realizzati in laterizio e travertino e distribuiti in maniera uniforme, richiamano l'idea di 'recinto' che ricorda la sacralità del luogo che riportano alle tipiche costruzioni romane.

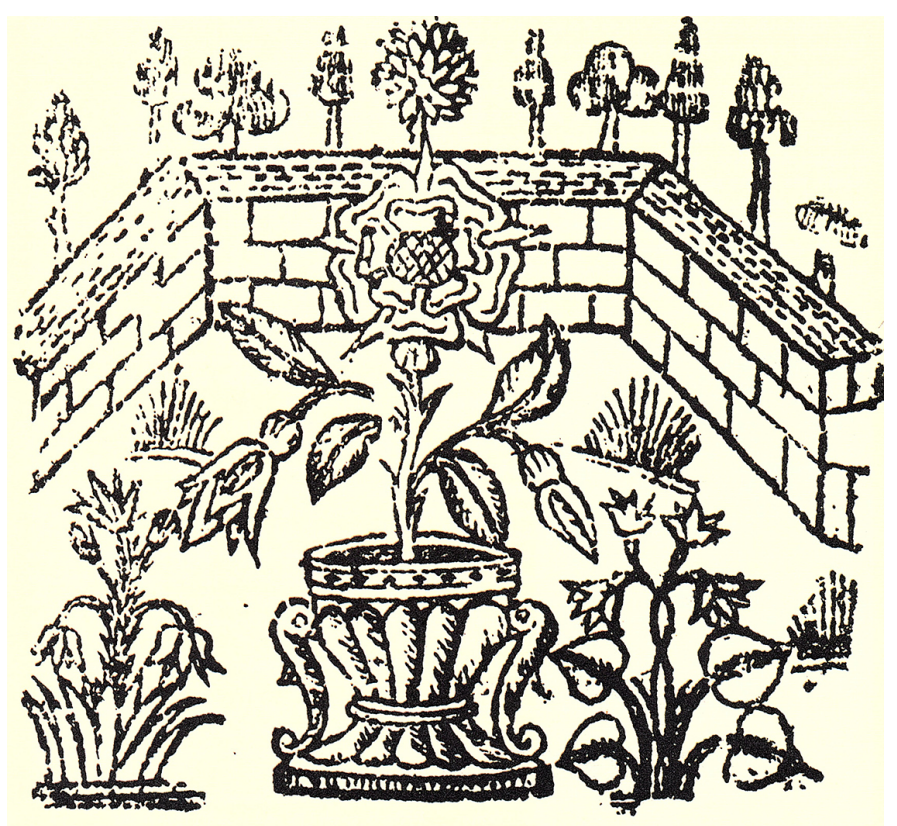

\section{Costruzione}

l'architetto concentra nella fascia centrale il fulcro distributivo delle principali funzioni del complesso relegando sul lato ovest (Via Belgio) le parti dedicate alle cappelle feriali, la fonte battesimale e gli uffici della sagrestia; tutte queste funzioni sono contenute dal setto longitudinale di bordo che crea un cortile stretto e lungo ha la funzione di isolare e separare dal muro perimetrale.

Nella parte est, sul lato via Germania invece, troviamo un vero e proprio giardino segreto, o meglio un Hortus Conclusus, un luogo santo, per pensare, un luogo di meditazione posto a stretto contatto con la chiesa e con la corte d'ingresso, ma diviso nettamente da un setto posto fra i due ambienti.

Vi si accede dal cortile interno della sagrestia e si rimane in 'contatto' con il resto del complesso mediante delle aperture sempre della dimensione di un modulo (quindi 2,20).

II restringimento della fascia laterale, mette in risalto ancor di più la struttura che si sviluppa nella zona centrale della maglia, evidenziandone maggiormente la matrice geometrica costitutiva, come ad esempio la corte d'ingresso, il giardino, rompendo la monotonia compositiva che è alla base stessa della maglia. 


\section{Ingresso}

Inoltre se ci dovessimo calare sul piano dell'osservatore che percorre lo spazio d'ingresso potremmo tranquillamente scorgere come questa disposizione sia volta ad amplificare percettivamente la dimensione spaziale dell'ambiente, lasciando intravedere solo le chiome delle essenze arboree del giardino laterale quasi fosse un luogo esterno all'intero complesso. Entrando dal cancello principale nel complesso dalla corte, veniamo subito indirizzati lungo il percorso da una fascia centrale pavimentata, posta planimetricamente nella mezzeria della maglia, della larghezza ancora una volta di un modulo di 2,20, decorata con dei disegni geometrici e simbolici lungo tutto il percorso, dei sectilia pavimenta che narrano una trama geometrica che sembra alludere alla disposizione spaziale del complesso, e ci 'accompagnano' in un percorso che culmina con l'altare (figg. I5, I6).

Il percorso posto asimmetricamente, organizza e gerarchizza tutto lo spazio in un rigore di perfezione geometrica, e diventa risolutivo per il proporzionamento dell'intero edificio, l'architetto ci consegna a 'guardar bene' la chiave di lettura dell'intera chiesa, le lastre quadrate del pavimento altro non sono che il modulo di costruzione dell'intero edificio. II parallelo è immediato nel pensare ad un chiaro riferimento classico dei templi antichi, dove grazie al modulo si poteva ricostruire tutto l'edificio. Qui l'elemento determinante è il quadrato.

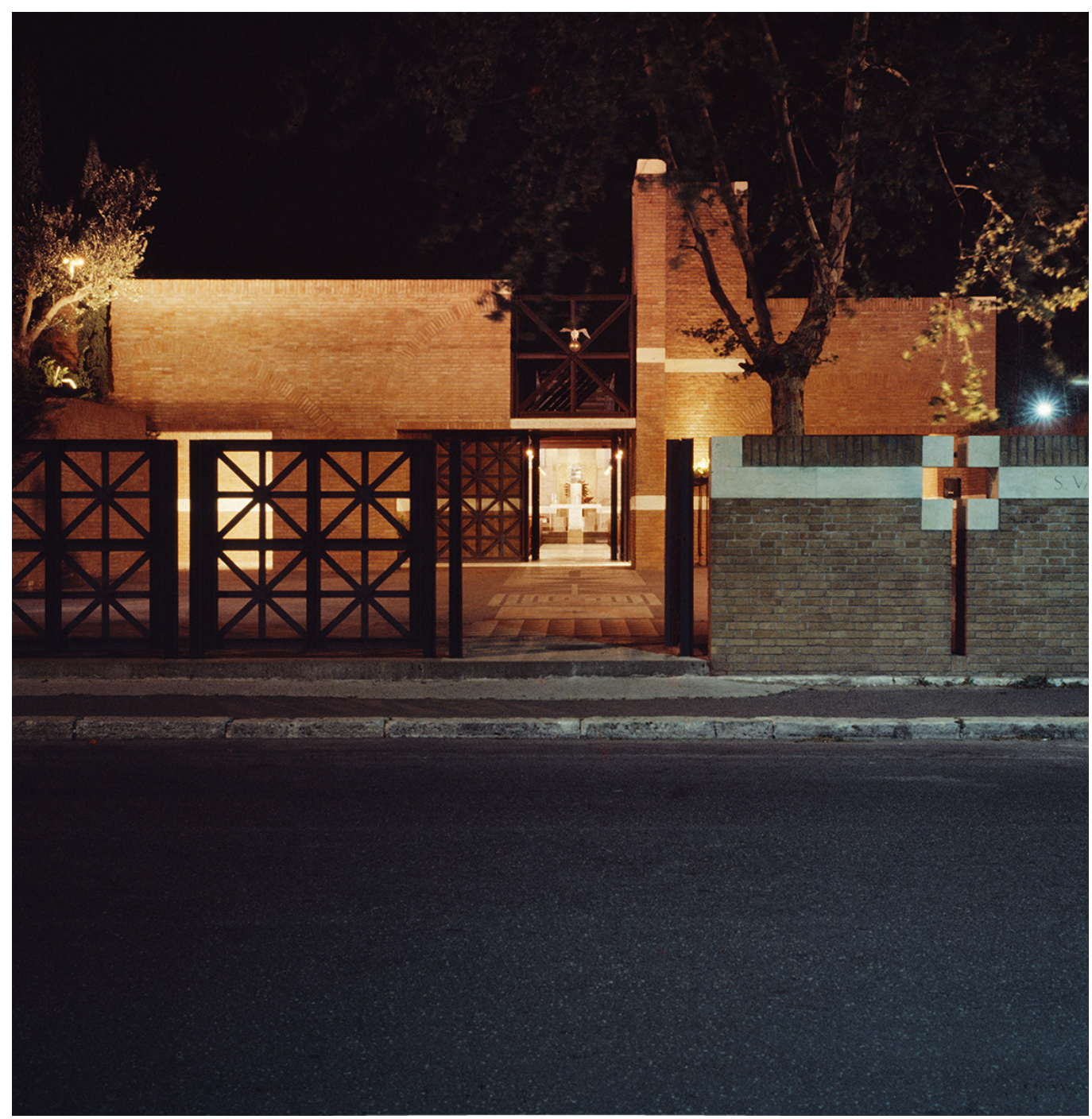




\section{Alzati}

Anche negli alzati si ritrova la costruzione attraverso giochi di pieni e di vuoti che denunciano percorsi e suggestivi contrasti di luce e ombra, composti da un'aggregazione basata sempre sul modulo quadrato di base 2,20. I prospetti articolati e irregolari a una prima osservazione danno l'idea del rudere, ma poi come si è detto si riesce a ricostruire il pensiero del disegno generativo.

\section{Conclusioni}

Probabilmente senza i disegni teorici, gli schizzi preparatori, le piante, i prospetti che abbiamo analizzato e studiato, saremmo in possesso soltanto di una parte della verità. Avendo conosciuto soltanto l'edificio costruito non ci avrebbe aiutato a comprendere in pieno il pensiero creativo di Francesco Berarducci, sarebbe stata un'operazione non esaustiva e non completa.

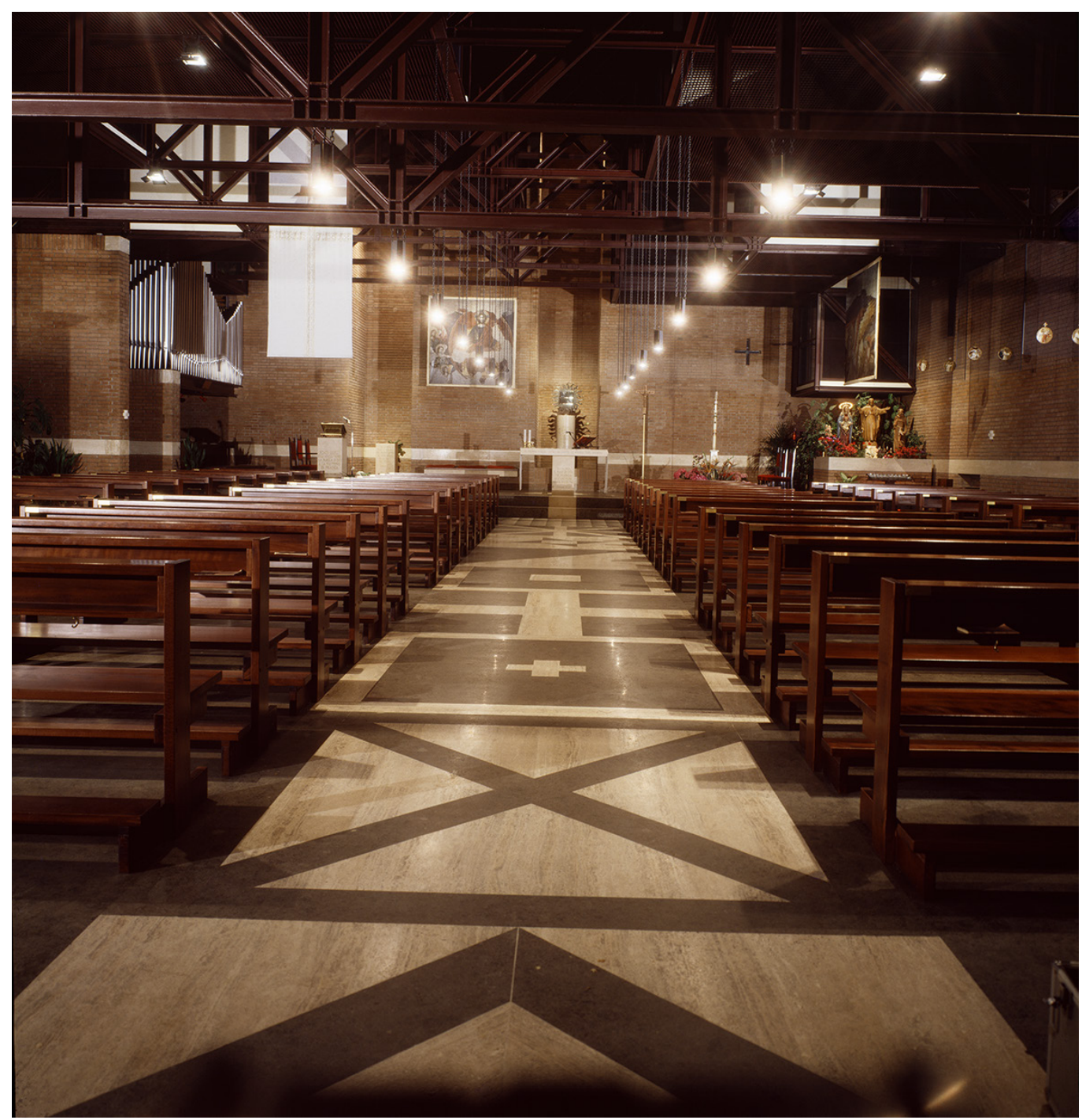


Fig. 17. Studio Berarducci, disegno dell'ingresso principale, dove son accennati i moduli compositivi.

Fig. 1 8. Disegno critico di studio del prospetto principale, dove si può vedere la rigida maglia quadrata tridimensionale come gerarchizza, organizza

e definisce il prospetto principale.

Fig. 19. Studio Berarducci, disegno dello spazio

interno della chiesa, dove si può vedere la rigida

maglia quadrata tridimensionale come definisce, organizza, gerarchizza,

e scandisce lo spazio

principale dell'aula.
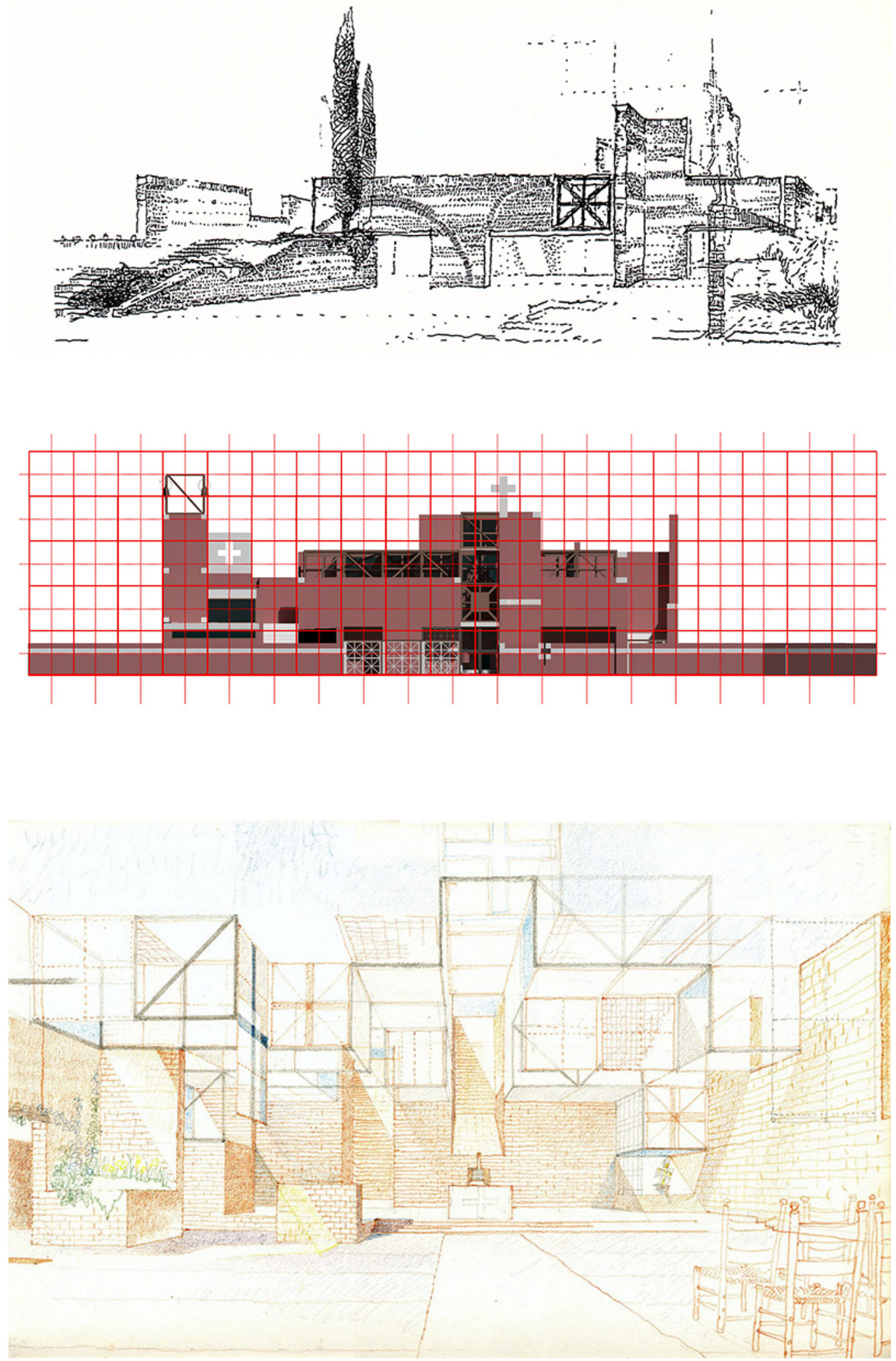
II disegno quindi non solo per 'fare architettura', ma anche per comprendere la genesi creativa più profonda, dice Roberto de Rubertis "che disegnare è stabilire un proposito, esporre un"intenzione, descrivere un programma" [de Rubertis 2002, p. I I] Quindi il disegno, tra le tante cose, è anche una manifestazione di intenzioni, di volontà del proprio modo di vedere la vita. Noi cercando tra le pieghe di questi schizzi impolverati, forse abbiamo rintracciato quei sparuti e flebili indizi che a volte possono chiarire le intenzionalità.

In san Valentino dove si è imposta un'immagine di rudere e di rovina corrotta, dove dietro l'apparente disgregazione muraria emerge poco a poco in filigrana tutta la filosofia e la visione creativa del pensiero generatore dell'autore. La memoria storica, il genius loci di Roma, la rigida maglia tridimensionale cubica, l'utilizzo dei materiali del luogo, tutto ciò ci consente di comprendere l'ineffabile senso che ogni architetto ha nel proprio animo, quel pensiero profondo di costruire cercando di dare senso a quello che sta facendo, di 'dare significato'. Su questa strada credo ci sia molto da fare e credo che esista una dimensione della storia dell'architettura che deve essere riscritta, rivisitata e riattualizzata alla luce di nuovi studi dove si cerchino di comprendere le varie tappe del processo creativo. Questo lavoro intellettuale occuperà credo parecchie generazioni di studiosi.

\section{Note}

[I] Francesco Berarducci nasce a Roma nel 1924. Ordinario di Composizione Architettonica all'Università La Sapienza di Roma, appartiene alla generazione di architetti romani che entra nella facoltà di Architettura subito dopo la guerra per laurearsi nel 1950 con medaglia d'oro della fondazione R. Almagià per il miglior laureato dell'anno. Suo compagno di corso è Carlo Aymonino, che, sotto la guida di Mario Ridolfi e Ludovico Quaroni, progetteranno il quartiere Tiburtino a Roma, la realizzazione più emblematica del neorealismo italiano. Francesco Berarducci prosegue con Ballio Morpurgo, con cui collabora alla progettazione del quartiere di Torre Spaccata a Roma, ed in seguito con Mario De Renzi. Architetto prolifico annovera moltissime opere realizzate, ricordiamo tra le più rilevanti, la sede centrale della Rai in viale Mazzini, la chiesa di san Valentino al villaggio Olimpico e diverse palazzine in Roma.

[2] Berarducci Carlo (1995). Disegni e pensieri di Francesco Berarducci, in Edilizia Popolare, a. XLII, n. 238, marzo-aprile 1995

[3] La città smarrita è il titolo di uno scritto inedito di Francesco Berarducci che ha come titolo secondario Tra le macerie della città radiosa. Si tratta di una riflessione teorica di ricerca sul tema della città e sullipotesi progettuale per una città lineare a partire dalla fine degli anni '70 e per tutti gli anni '80. Analisi e studio che si sostanziano attraverso gli strumenti specifici del comporre e del disegno.

L'aspetto più interessante è proprio quest'ultimo, ovvero la diretta consequenzialità tra lo scritto teorico, i disegni e la sua ipotesi progettuale.

L'idea è quella di una città lineare costruita sull'alveo di un fiume artificiale che funzione da infrastruttura viaria e tecnica, con gli spazi pubblici sul fondo ed un tessuto residenziale informale, casuale e modificabile costruito sulle due sponde con una matrice cubica.

[4] La pianta libera di Mies alleggerisce lo spazio dalla presenza di una struttura rigida e quindi libera anche l'involucro, in questo modo nei progetti di Mies, lo spazio non ha piu' confini è diviene uno spazio fluido, dinamico che scorre tra gli elementi, il tutto gerarchizzato da una griglia cartesiana che organizza i segni nello spazio. Dice Colin Rowe che Mies ha "una radicale revisione della capacità di concepire lo spazio". Infatti egli costruisce un nuovo linguaggio della moderna architettura, per la creazione di una nuova concezione e di un diverso rapporto con lo spazio, un'architettura che diventi il manifesto rappresentativo della propria epoca storica.

\section{Riferimenti bibliografici}

AAVV (1989). Chiesa al Villaggio Olimpico, Roma. In I premi nazionali In/Arch 1989. In L'architettura cronache e storia, n. 409, a. XXXV, n. II, pp. 77-8I6, ivi p. 807.

Benedetti Sandro (1990). L'architettura sacra della Diocesi Romana nel tempo del post-Concilio. In Quarta Biennale d'Arte Sacra. La Crocifissione, Stauròs Internazionale. Pescara: Umberto Sala Editore pp. 297-336, ivi pp. 306-309 (ripubblicato in Id. Architettura sacra oggi. Roma: Gangemi. 1995. pp. 173-189).

Berarducci Francesco, (1990). Introduzione. In Pontificia Opera per la preservazione della fede e la provvista di nuove chiese in Roma (a cura di). Guida alle nuove chiese di Roma, a cura della Pontificia Opera per la preservazione della fede e la provvista di nuove chiese in Roma. Roma-Reggio Calabria: Gangemi, pp. I4- 15.

Berarducci Francesco (1990). Scheda n. 7. In Pontificia Opera per la preservazione della fede e la provvista di nuove chiese in Roma (a cura di). Guida alle nuove chiese di Roma. Roma-Reggio Calabria: Gangemi Editore, pp. 32-33.

Berarducci Francesco (1998). San Valentino al Villaggio Olimpico, Roma. Il respiro della città eterna, in Chiesa Oggi, a. 7, n. 30, pp. $20-23$

Campagna Marina, Melograni Francesco, Francesco Berarducci (1989). Chiesa di San Valentino al Villaggio Olimpico, Roma. In Costruire in laterizio, a. 2, n. 12, pp. 396-402. 
de Rubertis Roberto (1987). Progetto come rappresentazione della preesistenza. La Chiesa di S. Valentino di Francesco Berarducci. In XY, dimensioni del disegno, n. 4, pp. 45-52.

D'Ugo Paolo (1988). Complesso parrocchiale di S. Valentino al Villaggio Olimpico, Roma. In Spazio e società n. 43, a. XI, pp. 82-85.

Frediani Gianluca (1997). Le chiese. Roma-Bari: Laterza.

Muratore Giorgio (2006). Architetti romani del Novecento nella metamorfosi dello spazio sacro, In Stefano Mavilio (a cura di), Guida all'architettura sacra. Roma. 1945-2005. Milano: Electa, pp. I I-2 I, ivi I9-20.

Purini Francesco (1993). Unica e molteplice, in L'Arca n. 68, pp. 4-I I.

Rossi Piero Ostilio (2000). Roma. Guida all'architettura moderna. 1909-2000 (in collaborazione con Ilaria Gatti). Roma-Bari: Laterza, scheda 195, p. 339.

Villani Paola, (2006). San Valentino. In Stefano Mavilio (a cura di). Guida all'architettura sacra. Roma. 1945-2005. Milano: Electa pp. $102-10$.

Zoffoli Paolo (1988). Chiesa di San Valentino al Villaggio Olimpico, Roma. In L'industria delle costruzioni, n. 20 I-2, a. XXII, pp. 18-25.

\section{Autori}

Luca Ribichini, Sapienza Università di Roma, luca.ribichini@uniromal.it

Lorenzo Tarquini, Sapienza Università di Roma

Mario Ciamba, Sapienza Università di Roma

Ivan Valcerca, Sapienza Università di Roma

Massimiliano Mastracci, Sapienza Università di Roma

Per citare questo capitolo: Ribichini Luca,Tarquini Lorenzo, Ciamba Mario,Valerca Ivan, Mastracci Massimiliano (2020). Genesi di una forma tra idea, geometria e materia, Francesco Berarducci. Analisi della Chiesa di San Valentino al Villaggio Olimpico/Genesis of a form: idea, geometry and matter. Francesco Berarducci. Analysis of the church of St.Valentine, Olympic Village, Rome. In Arena A., Arena M., Brandolino R. G., Colistra D., Ginex G., Mediati D., Nucifora S., Raffa P. (a cura di). Connettere. Un disegno per annodare e tessere. Atti del $42^{\circ}$ Convegno Internazionale dei Docenti delle Discipline della Rappresentazione/Connecting. Drawing for weaving relationships. Proceedings of the 42th International Conference of Representation Disciplines Teachers. Milano: FrancoAngeli, pp. 1385-1410. 


\title{
Genesis of a Form: Idea, Geometry and Matter. Francesco Berarducci. Analysis of the Church of St. Valentine, Olympic Village, Rome
}

\author{
Luca Ribichini \\ Lorenzo Tarquini \\ Mario Ciamba \\ Ivan Valcerca \\ Massimiliano Mastracci
}

\section{Abstract}

The parish complex of S.Valentino is located inside the Olympic Village in Rome. The buildings created to house the athletes participating in the 1960 Olympic Games in Rome will later be transformed into a real neighborhood.

In 1979 the architect Francesco Berarducci was commissioned to carry out the project for the current church. Through his ideal and utopian designs we can try to better understand his vision of the world and its architecture. Through these small pieces of paper, sometimes wrinkled and damaged, we find the philosophy of intervention and the founding values of our research. We can say without emphasis that these sketches represent the very essence of Berarducci's thinking towards the theme of the church. At the center of his reflection Berarducci hoped and affirmed the need for a return to a more linear and calm formal language that would highlight the spiritual serenity of the ecclesiastical building. The reference model is Roman architecture

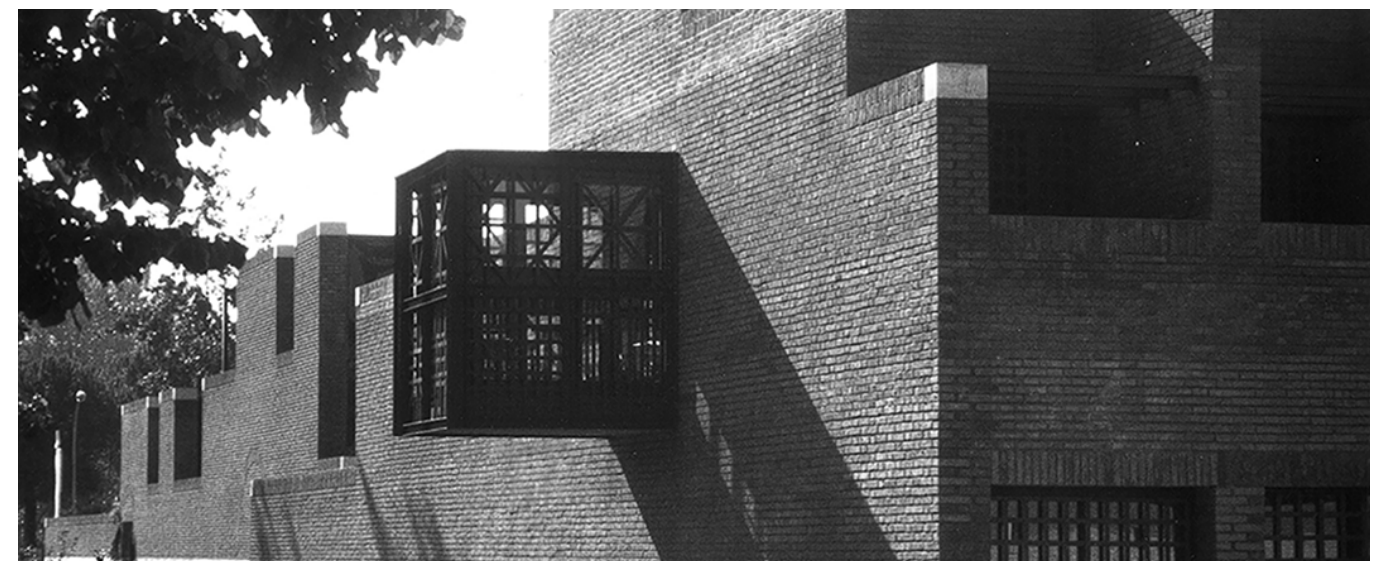




\section{Introduction}

Designing a building or architectural space starts with a primogenial idea or a study often triggered by a series of sketches or preparatory drawings which have the undeniable merit of crystallising the architect's intentions.

For example, Palladio who elaborated on several hypotheses based on a specific theme; he achieved this by using a method to investigate several possible variants until he had a considerable number of possible solutions (fig. I).

In some cases many architects have avoided developing either a particular process or a personal method to define a 'form'.

Others instead have adopted a visible, discernible strategy; they fine-tune and use what is often a very strict method, above all in their sketches and preparatory and final drawings. All one needs is the patience to be able to 'see' and interpret their design drawings.

Observation is, as always, decisive; whatever the discipline, it involves constant patient analysis. The observer's sensitivity, attention and precision sparks new interpretations. Sometimes all it takes to either spark new interpretative scenarios or introduce new truths is a distinguishing characteristic, information inspired by new comprehensive insight, or identification of a significant detail.

Francesco Berarducci [I] is one such architect. In the church of St.Valentine in the Olympic Village in Rome we were able to appreciate the creative genesis of the building by carefully studying his drawings and reading his written notes.

Trying to identify the procedural and imaginative lines at the beginning of the creative process is not a sterile activity or end in itself; it ambitiously aims at shedding light on 'how' and 'why' an architect comes to ultimately establish a precise architectural form.

Fig. I. Andrea Palladio, Several different layouts for the same building, perhaps Palazzo Volpe in Vicenza (in: R. de

Rubertis, Il disegno dell'architettura, Roma, 2002, pag |58)

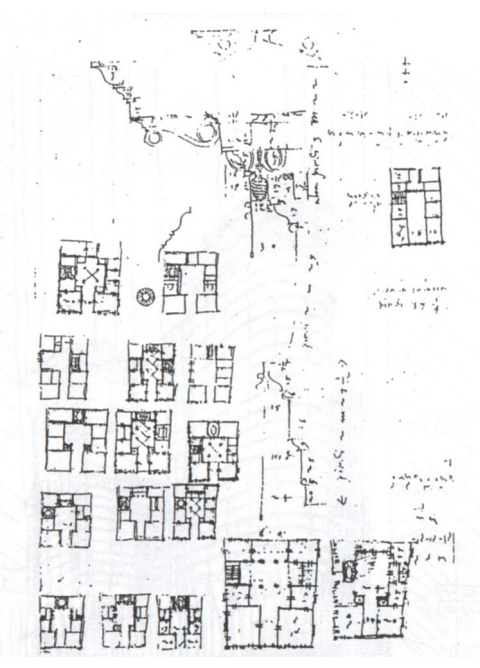

\section{French Method}

The method that uses a 'genetic' approach to study the auroral phase of a creative composition was invented in France, primarily in literature. In fact, several manuscripts of numerous French poets and writers such as Hugo, Verlaine and Baudelaire contain alterations, rethinks, and changes. Studying their writings made it possible to trace the creative evolution of their works from the first draft to the final version.

These sheets provide us with greater in-depth knowledge of each author's motivation. Mutatis mutandis, in architecture the crumpled pieces of paper on which architects draw their first sketches, or drawings accompanied by notes in the margin, reveal their intentions 
and methods. More often than not these pieces of paper are frequently and unfortunately thrown away or, at the end of the project, stuffed into a dusty drawer. This was the spirit that prompted us to review the preparatory drawings of the church of St.Valentine in the Olympic Village in order to understand its composition, much as we would a literary work.

Fig. 2. Studio Berarducci, theoretical project of city; note the networ
of buildings sketched using a design based on the concept of module and grid.

Fig. 3. Studio Berarducci, studio sketch for the city; hypothesis of a splintered structure; note the generative grid that exploits the cube as its module.
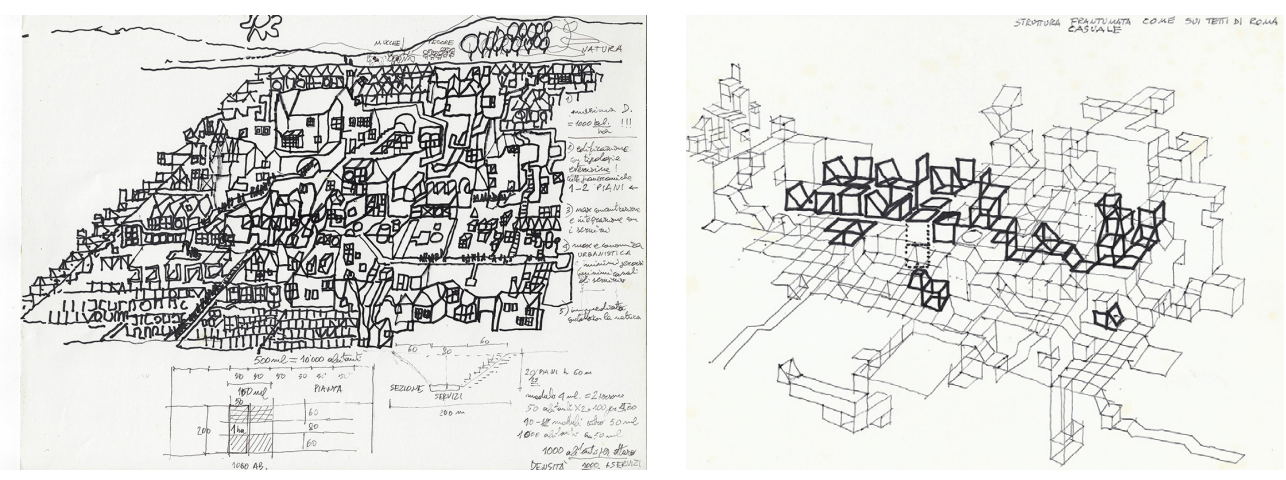

\section{The Church}

The church of St.Valentine in the Olympic Village was designed in 1979 and inaugurated in 1987; it stands nearViale XVII Olimpiade (on the corner of Via Germania) in the district built for the athletes of the 1960 Olympics, thus its name Olympic Village.

The urban context stretches between Villa Glori and the old Roman road of Via Flaminia where in this case the parish complex is a compact, well-defined block.

In the seventies and eighties the quality and identity of churches and parish complexes needed to be updated; the key idea was to design buildings with an eye on "environmental context, liturgical hospitality, artistic expression, and the latest pastoral requirements" [Vatican Council II].

The creative concept behind the design was to propose a complex capable of generating a strong link between the old and the modern; on the one hand the power and union of tradition and cultural legacy, on the other, crisp innovation in line with the most modern architectural concepts.

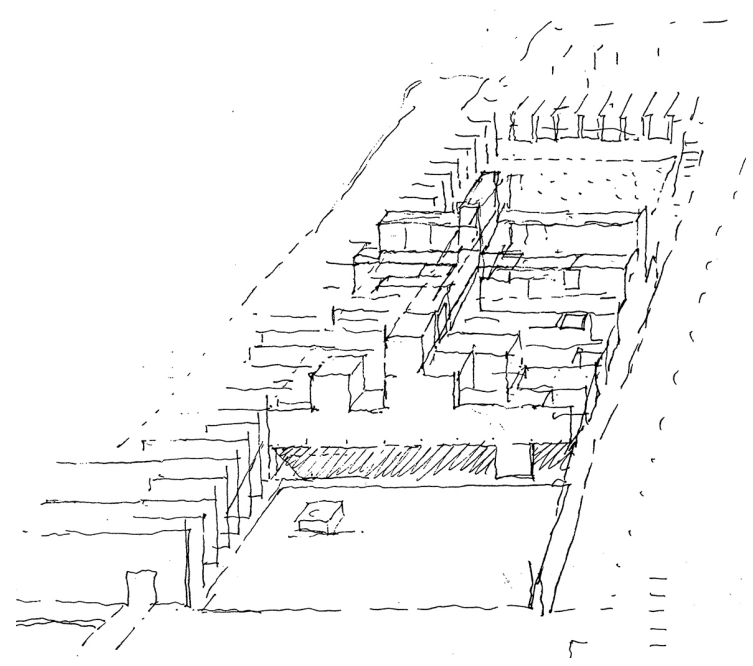

Fig. 4. Studio Berarducci, volumetric studio sketch for the church of St

Valentine in the Olympic Village; note how the generative and aggregasquare or cubic module. 
Francesco Berarducci's design was selected as the winning project. To satisfy the ecclesiastical requirements he had proposed three scenarios: reinstatement of the link with tradition; adherence to the liturgical indications of the Second Vatican Council; and, finally, pragmatic and economical solutions dictated by pastoral requirements.

Berarducci reinforced his design with the following words: "After a phase of anxious experimental research, hopefully we will return to the spiritual serenity generative of sure intentions and a peaceful formal language. Only then will new, stricter architectural figurations be able to re-evoke the profound cultural message of our centuries-old ecclesiastical tradition" [Berarducci 1955] [2].
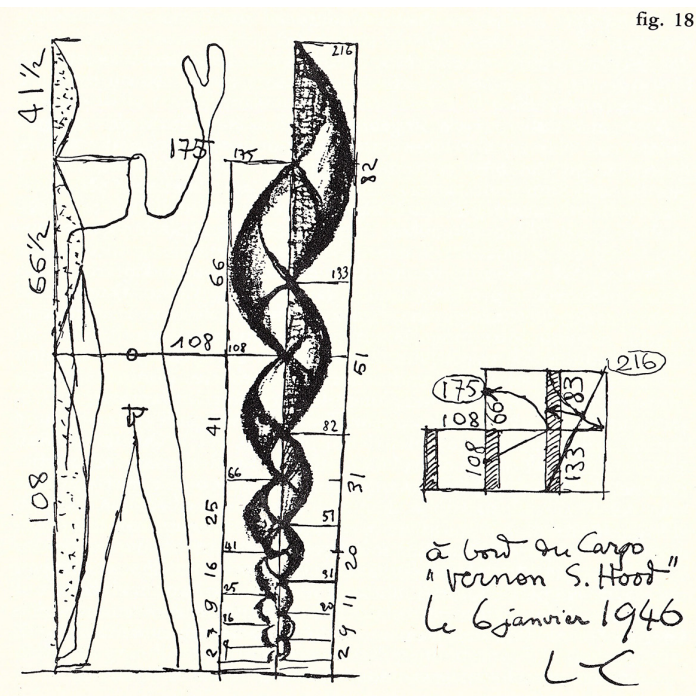

\section{Geometry and symbols}

The square, or better still the cube, is the key element in the architectural design of the church; it is visible in several preparatory drawings and the real life image of the church. This shape was a long time in the making; it probably emerged initially from a group of drawings, images and written notes focusing on the idea of a theoretical linear city and dated between 1979 and 1982 [3]. In these drawings Berarducci theorised an urban fabric inspired by a series of spontaneous cubic aggregations, inevitably conjuring up typical images of Mediterranean cities (i.e., Greece, Amalfi, Positano, or other north-African cities (figs. 2, 3).

The concept of this theoretical city designed and imagined throughout Berarducci's long professional career comes together and crystallises in the church of St.Valentine where he applied his theoretical principles in a real building to be designed and constructed.

He uses the square as a symbol expressing affiliation and sacredness, a contracted form of contemplation and its identity, linked to the principle of earthly life. The square is the key figure of space, juxtaposed against the circle or spiral often symbolising time; but the square is also the symbol of the universe created in opposition to chaos and the uncreated. In the extensive literature that exists regarding the cube it also represents the symbol of wisdom, truth and moral perfection; one of the many references is the model of Celestial Jerusalem and its three equal dimensions cited in the Apocalypse.

In 1960 Bruno Munari uses these words to introduce the square in his monograph:

"The square is the extreme concentration of a spatial idea that is complete in itself. It represents an order of meaningul spiritual symbolism. All the other rectangles, with different sides, refer to the square as a weakening of its law through expansion in height or width" [Munari 1960]. 

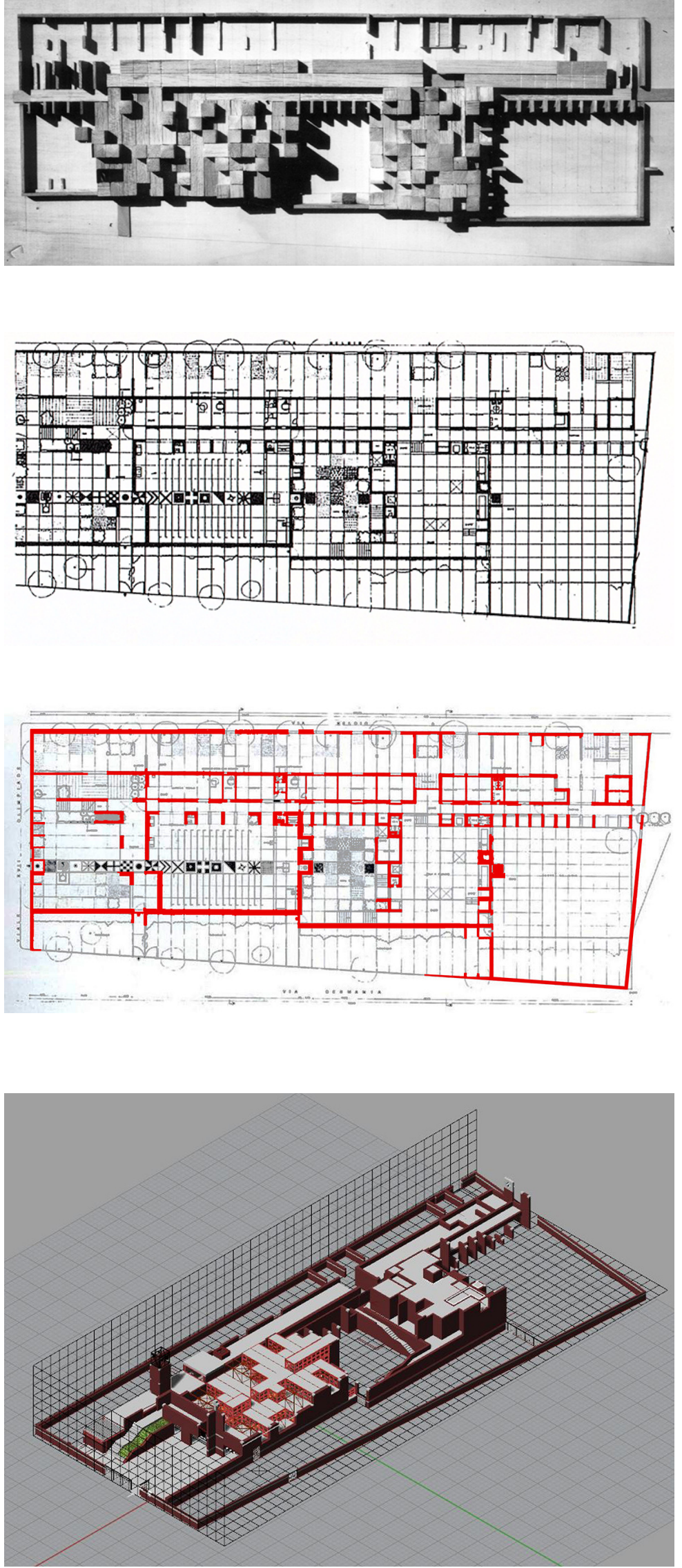
Fig. 10. Mies Van der Rohe, Exhibition House German Building Exhibition, Berlin 1931, plan.

Fig. I I. Mies Van der Rohe, Pavilion at the Barcelona 1929, plan.

Fig. 12. Mies Van der Rohe, Pavilion at the International Exposition Barcelona 1929, diagram.
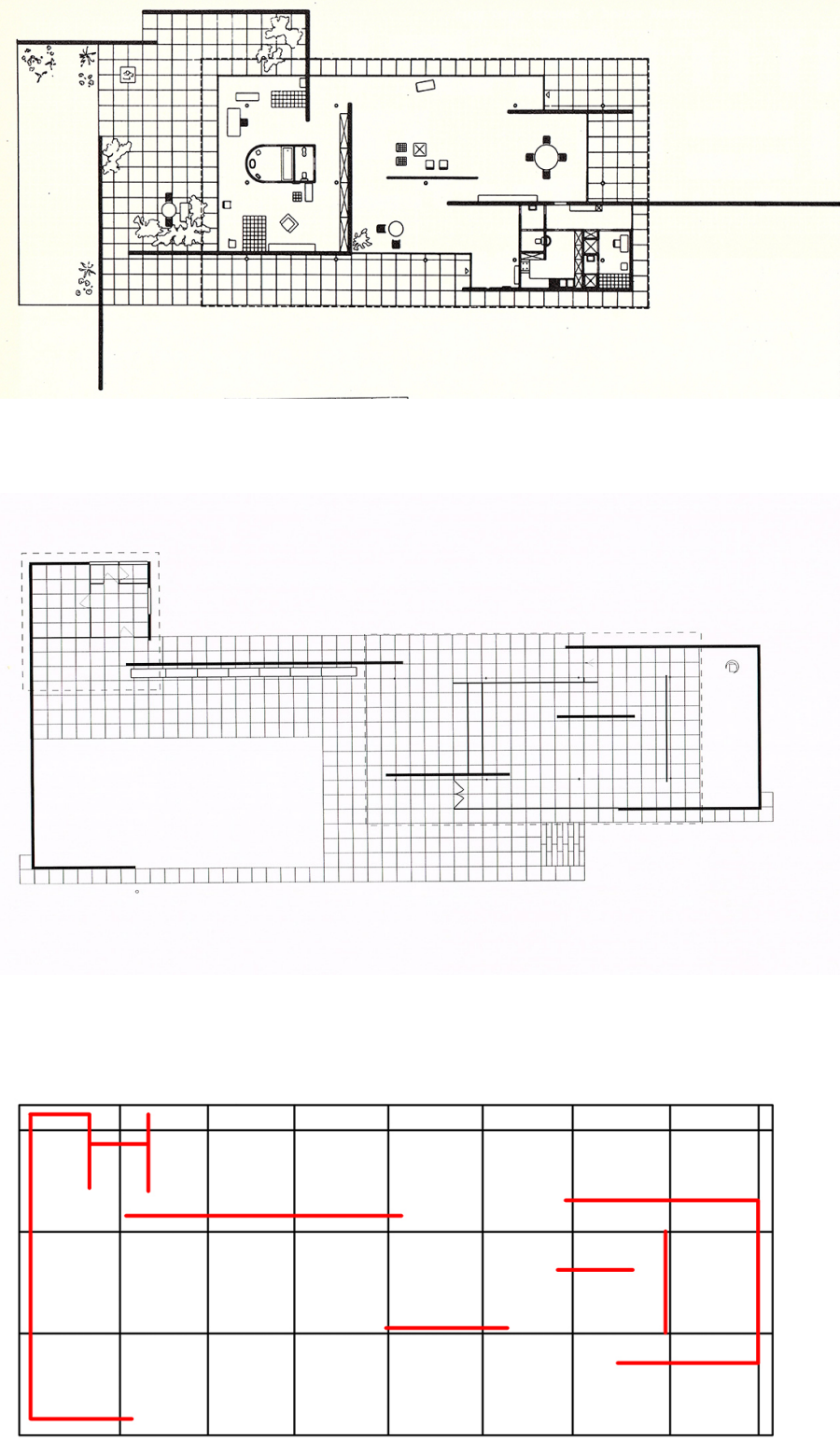

The modular idea of the spatial conformation (plan and elevation) of the church of St. Valentine in the Olympic Village was inspired by a Cartesian division of abscissa and ordinates; when they intersect they generate the form and space to be used for the ecclesiastical functions and therefore, by their very nature, become sacred.

Berarducci created a reticular grid based on the square; when planimetrically described it develops upwards and in space, maintaining its dimensions and compositional rhythm and thereby establishing the cube as the generating solid.

The double ratio, in plan and elevation, is easy to recognise in the entrance where the rhythm of solid and empty spaces characterises the façade and creates beautiful, geometrically recognisable and coherent shadows (figs. 17, 18).

The $2.20 \mathrm{~m}$ base of the module suggests that the architect paid special attention to the human scale, establishing a relationship between the latter and the spatial result, a concept reminiscent of Le Corbusier's Modulor and Leonardo's Vitruvian Man (fig. 5). 
When establishing the overall form Berarducci qualifies space by adding another connotative factor that identifies and inserts the architectural object in the Roman cultural milieu, thereby maintaining a strong expressive link with the historical environment. He uses an aggregation that tends to alter the pure geometric conformation and establish a formal 'incompleteness' that destroys the temporal bond, corrupter of matter, and projects the building into timelessness. By exploiting a mnemonic process Berarducci gives free rein to the imagination, almost as if it were an unfinished work by Michelangelo that rises into a metaphysical space and reincarnates the sacredness of Roman ruins.

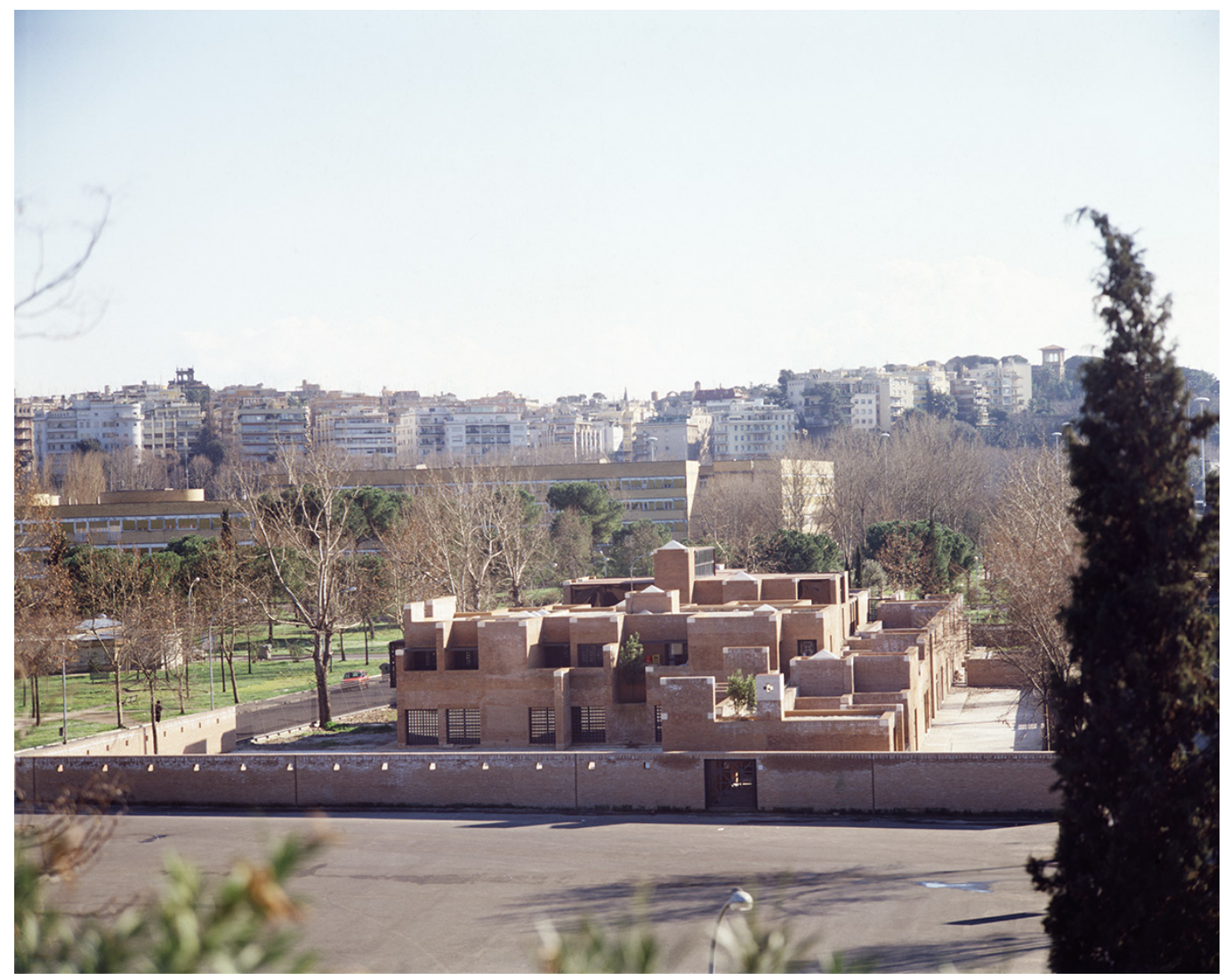

\section{Measure, Module, Parameter}

The entire planimetric layout appears to have been generated by a $2.20 \mathrm{~m}$ square module, both for the plan and elevation (figs. 6, 7).

In fact, when the ecclesiastical complex is viewed from above it is easy to see the different functional areas: the entrance courtyard, the church, the inner courtyard, the sacristy and the sports fields. All these areas are superimposed on a square grid extending longitudinally and transversally and creating a network of $2.20 \mathrm{~m}$ square modules which, as mentioned earlier, spatially and hierarchically structure the entire surface area of the parish complex.

If this is true, then evidently St. Valentine in the Olympic Village shares several similarities with the generative, spatial and design concepts of two great masters; Mies van der Rohe [4] and Louis Kahn.

Berarducci designed the building based on Mies' spatial rules, but he added an important variant: he also focused on the site where the building was to stand. 
Fig. 14. A garden consiered as paradise where the rose blooms, symbolically representing Eden it is a place reserved for reflection and meditation of the spirit and regeneration of the soul.
This reveals Berarducci's tradition as a Roman architect who studied in the important, prestigious Roman School where memory was crucial in the design of a project.

In this case the genius loci of Rome substantiate the concept of ruin and fragment 'in the form'. Reference to Louis Kahn is inevitable. The American master suggests what architecture should be, and what a brick should be. Berarducci is in no doubt: the presence of ancient Rome must be substantiated in the brick walls.

Obviously the 'generative' grid not only completely covers the lot, it also determines the parish boundary. In fact the perimeter walls to the west (Via Belgio) and south (Via della XVII Olimpiade) perpendicularly follow the pattern of the grid; instead along the north side (Via Irlanda) and east side (Via Germania) the partitions are inevitably aligned along the previous boundary vis-à-vis their respective roads next to the complex (fig. 13).

The uniformly distributed brick and travertine walls are reminiscent of the concept of 'fencing' recalling the sacredness of the place - a typical trait of Roman constructions.

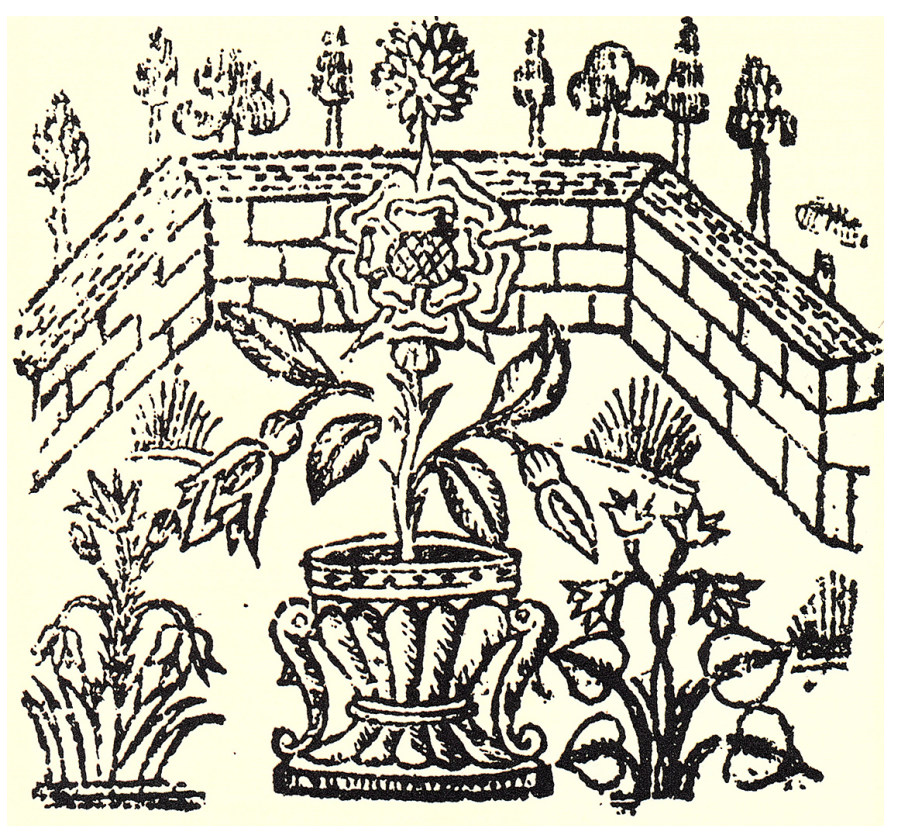

The construction

Berarducci places the distributive fulcrum of the main functions of the complex in the central strip, relegating the weekday chapels, baptismal font and sacristy offices to the west side (Via Belgio). All these functions, located in the longitudinal boundary partition, create a long narrow corridor intended to isolate and separate the perimeter wall.

A secret garden, or better still a Hortus Conclusus, is located to the east along Via Germania; this sacred spot where people can pause, think and meditate is very close to the church and entrance courtyard, although there is a partition between the two areas.

Access is through the inner courtyard of the sacristy; 'contact' with the rest of the complex is guaranteed by the openings, again measuring the dimension of the module $(2.20 \mathrm{~m})$.

Narrowing the area around the sides further emphasises the structure located in the centre of the grid and increasingly underscores the geometric matrix, for example the entrance courtyard and garden; this breaks the compositional monotony used as the basis for the grid. 


\section{The entrance}

If we were to enter the complex as a visitor and walk across the entrance area we could easily observe that this layout was intended to perceptively amplify its spatial dimension; all we would be able to see were the tops of the trees in the adjacent garden, almost as if it were located outside the complex.

Visitors entering the courtyard through the main gate are immediately directed along a paved central pathway planimetrically placed in the middle of the grid; the width of the walkway is yet again a $2.20 \mathrm{~m}$ module decorated with geometric and symbolic images from start to finish; these sectilia pavimenta reveal a geometric pattern ostensibly alluding to the spatial layout of the complex and 'accompanying' us along the path to the altar (figs. I5, 16). The asymmetric pathway structures and hierarchizes the entire space by using strict geometric perfection that becomes crucial when proportioning the whole building; the architect asks us to 'look closely' at the key to interpret the church because the square pavement slabs are nothing but the module constructing the whole building. There is an immediate parallel in this clearly classical reference to ancient temples where thanks to the module it was possible to rebuild the entire building. In this case the square is the all-important element.

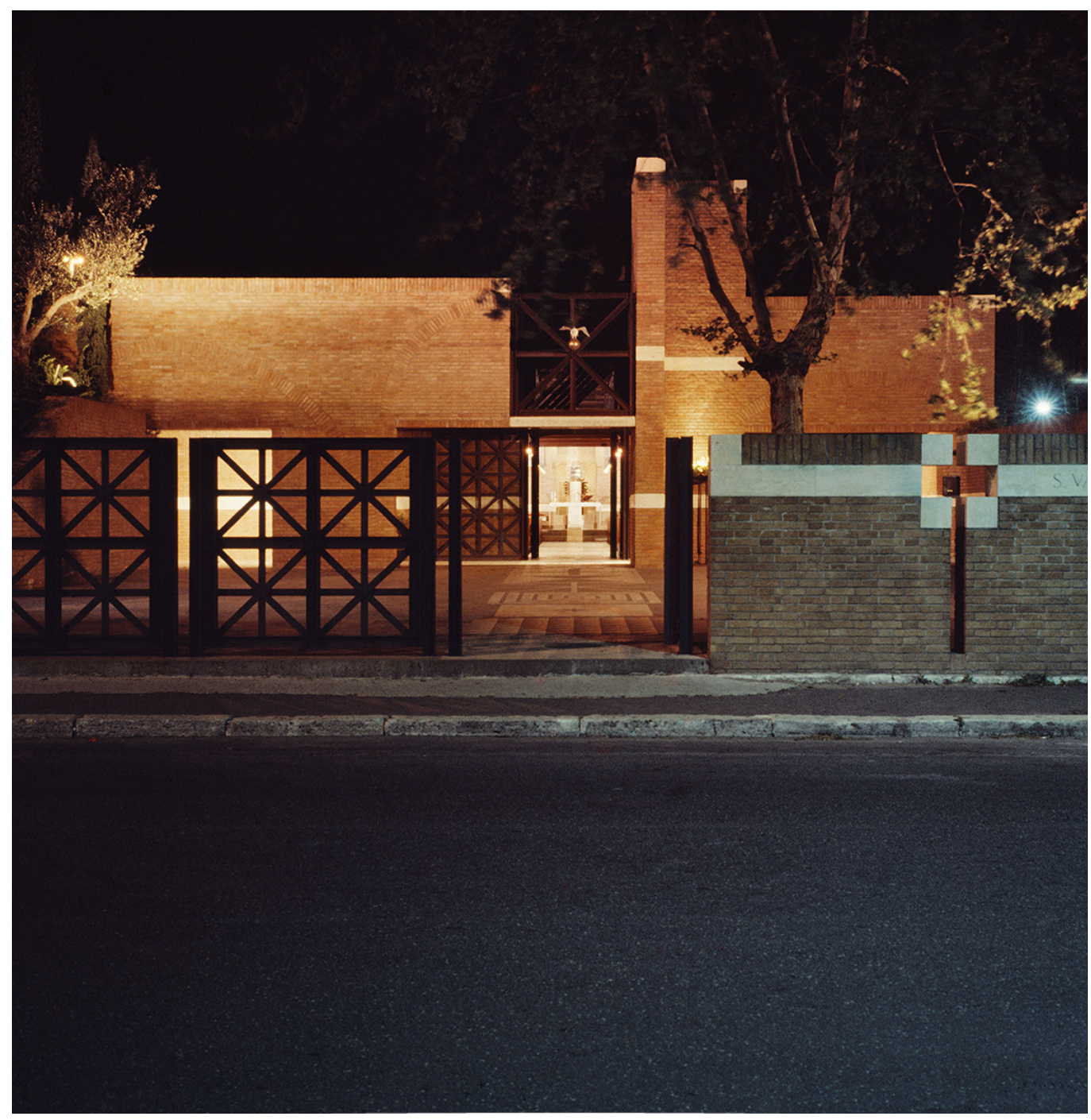




\section{Elevations}

The construction is present even in the elevations thanks to the solid and empty spaces that create pathways and beautiful light and shadow contrasts; this aggregation is again based on the basic $2.20 \mathrm{~m}$ square module. At first sight the multifaceted, irregular elevations appear to look like a ruin, but then, as mentioned earlier, onlookers can piece together the idea behind the generative design.

\section{Conclusions}

It's very possible that without the theoretical drawings, preparatory sketches, plans and elevations we analysed and studied we would only know part of the truth. Being familiar only with the built architecture would not have helped us fully understand Francesco Berarducci's creative idea; it would have been an incomplete and unthorough operation.

Drawings are therefore important not only 'to create architecture', but also to understand the more profound creative genesis of an artefact: Roberto de Rubertis says that drawing establishes a proposal, reveals an intention, and describes a programme [de Rubertis 2002, p. I I]. So drawing is, amongst other things, a manifesto of intentions, of the desire to reveal

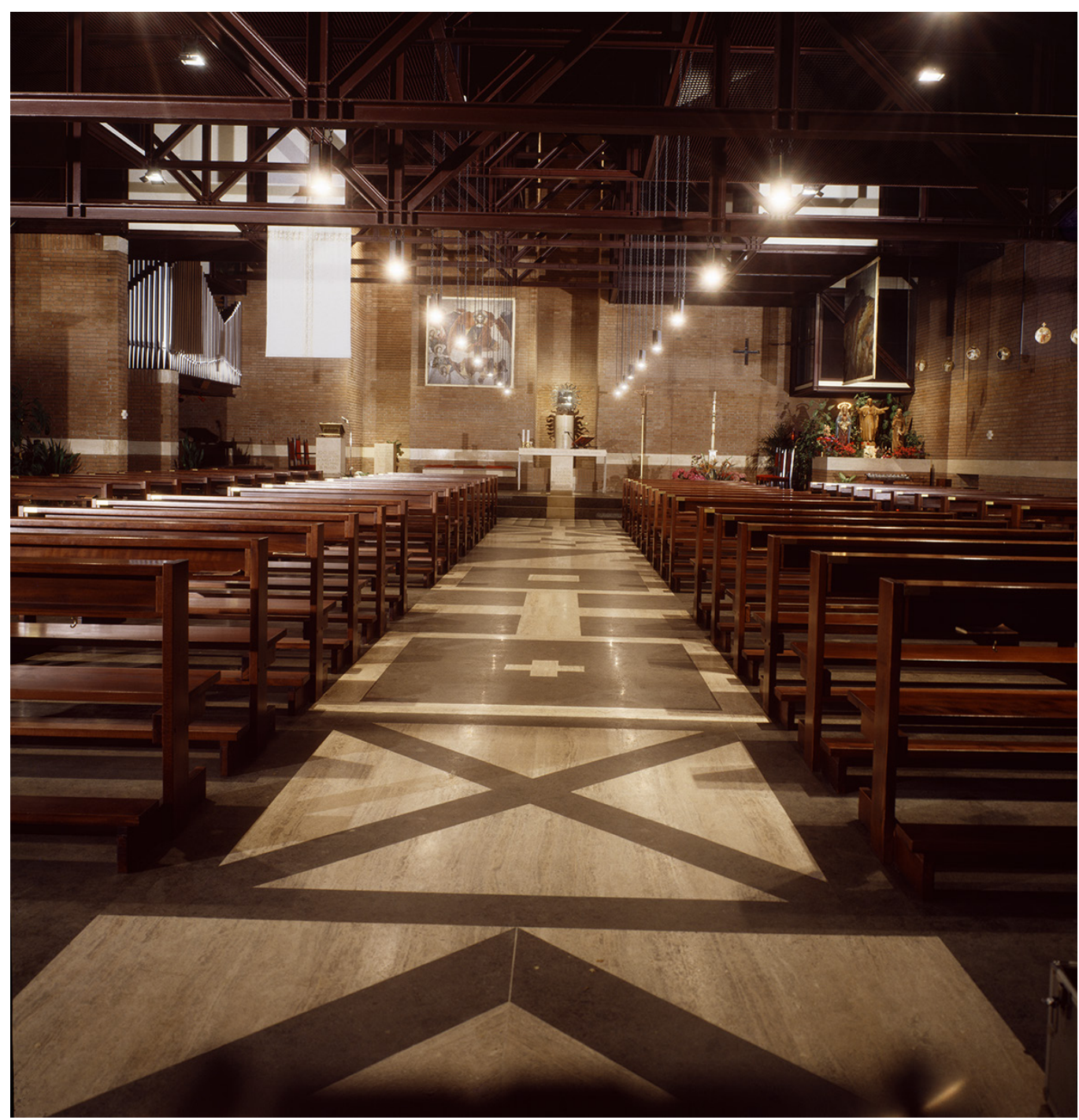


Fig. 17. Studio Berarducci, Drawing of the main entrance revealing the
compositional modules.

Fig. 18. Important studio drawing of the main elevation showing how the rigid three-dimensional square grid hierarchizes, structures and defines the main elevation.

Fig. 19. Studio Berarducci, drawing of the interior of the church showing how the rigid three-dimensional square grid defines, structures, hierarchizes and marks the main space of the nave.
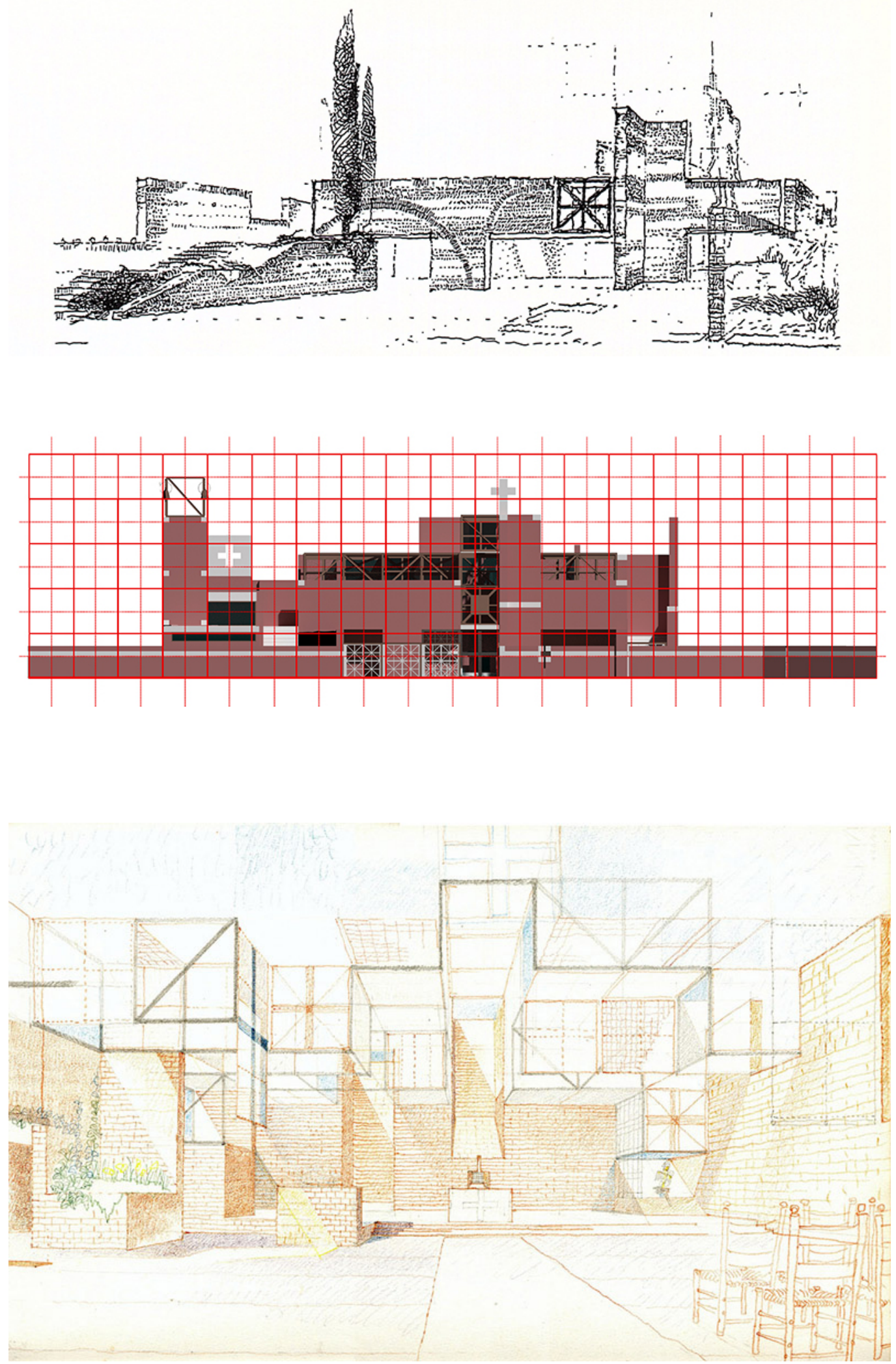
one's own personal way of seeing the world. By searching between the lines of these dusty sketches we have perhaps uncovered the few, faint clues that can, at times, clarify an author's intentions.

St. Valentine imposes the image of a derelict, rundown ruin; behind the noticeable breakdown of the walls the philosophy and creative vision of the author's generative idea emerges little by little in filigree. The historical memory, the genius loci of Rome, the rigid three-dimensional cubic grid and the use of local materials all allow us to understand the ineffable sense every architect has in his soul: the deep-rooted idea of building by trying to make sense of what he or she is doing, and 'bestow meaning'.

In this regard I believe there is still much to be done; I am convinced that some parts of the history of architecture should be rewritten, revisited and updated in view of the new studies that attempt to unravel the individual steps that exist in a creative process. This intellectual endeavour will, I believe, be a task for many generations of scholars.

\section{Notes}

[I] Francesco Berarducci was born in Rome in 1924. Full professor of Architectural Composition at "La Sapienza" University of Rome, he belonged to the generation of Roman architects who began their studies at the Faculty of Architecture immediately after the war. He graduated in 1950 and was awarded a gold medal by the R. Almagia Foundation for having graduated first in his class that year. One of his fellow students was Carlo Aymonino; supervised by Mario Ridolfi and Ludovico Quaroni, together they designed the Tiburtino district in Rome - the most emblematic example of Italian neo-realism.

Francesco Berarducci continued to work with Ballio Morpurgo on the design of the Torre Spaccata district in Rome and then later with Mario De Renzi.

He was a prolific architect and designed many buildings; the most important are the headquarters of RAITV in Viale Mazzini, the church of St.Valentine (Olympic Village) and several small townhouses in Rome.

[2] Berarducci Carlo, Disegni e pensieri di Francesco Berarducci, in "Edilizia Popolare”, year XLII, n. 238, March-April 1995.

[3] "La città smarrita" is the title of an unpublished text by Francesco Berarducci with the following subtitle: "Tra le macerie della città radiosa" [Between the rubble of a radiant city]. During his theoretical deliberations Berarducci researched the theme of the city and the hypothetical design of a linear city; his research lasted from the seventies to the end of the eighties. He used specific tools - composition and drawing - to conduct his analysis and study.

His drawings are the most interesting, i.e., they are a direct consequence of the architect's theoretical ideas, sketches and hypothetical design.

His idea of a linear city involved the bed of an artificial river acting as a technical and vehicular infrastructure, with public spaces at the bottom and an informal, casual and modifiable residential fabric built on the two banks; the design was based on a cubic matrix.

[4] Mies' free plan unburdens space from the presence of a rigid structure and thus frees the envelope. In Mies' designs this means that space has no boundaries and becomes dynamic and free-flowing between the elements; everything is hierarchised by a Cartesian grid organising signs in space. Colin Rowe says that Mies "radically revised the ability to conceive space". In fact he invented a new language of modern architecture and created a new concept and different relationship with space; this architecture became the manifesto of its own age.

\section{References}

AAVV (1989). Chiesa al Villaggio Olimpico, Roma. In I premi nazionali In/Arch 1989. In L'architettura cronache e storia, n. 409 , a. XXXV, n. II, pp. 77-8I6, ivi p. 807.

Benedetti Sandro (1990). L'architettura sacra della Diocesi Romana nel tempo del post-Concilio. In Quarta Biennale d'Arte Sacra. La Crocifissione, Stauròs Internazionale. Pescara: Umberto Sala Editore pp. 297-336, ivi pp. 306-309 (ripubblicato in Id., Architettura sacra oggi. Roma: Gangemi. 1995. pp. 173-189).

Berarducci Francesco, (1990). Introduzione. In Pontificia Opera per la preservazione della fede e la provvista di nuove chiese in Roma (a cura di). Guida alle nuove chiese di Roma, a cura della Pontificia Opera per la preservazione della fede e la provvista di nuove chiese in Roma. Roma-Reggio Calabria: Gangemi, pp. I4- 15.

Berarducci Francesco (1990). Scheda n. 7. In Pontificia Opera per la preservazione della fede e la provvista di nuove chiese in Roma (a cura di). Guida alle nuove chiese di Roma. Roma-Reggio Calabria: Gangemi Editore, pp. 32-33.

Berarducci Francesco (1998). San Valentino al Villaggio Olimpico, Roma. Il respiro della città eterna, in Chiesa Oggi, a. 7, n. 30, pp. 20-23

Campagna Marina, Melograni Francesco, Francesco Berarducci (1989). Chiesa di San Valentino al Villaggio Olimpico, Roma. In Costruire in laterizio, a. 2, n. 12, pp. 396-402.

de Rubertis Roberto (1987). Progetto come rappresentazione della preesistenza. La Chiesa di S. Valentino di Francesco Berarducci. In XY, dimensioni del disegno, n. 4, pp. 45-52. 
D'Ugo Paolo (1988). Complesso parrocchiale di S. Valentino al Villaggio Olimpico, Roma. In Spazio e società n. 43, a. XI, pp. 82-85.

Frediani Gianluca (1997). Le chiese. Roma-Bari: Laterza.

Muratore Giorgio (2006). Architetti romani del Novecento nella metamorfosi dello spazio sacro, In Stefano Mavilio (a cura di), Guida all'architettura sacra. Roma. 1945-2005. Milano: Electa, pp. I I-2I, ivi 19-20.

Purini Francesco (1993). Unica e molteplice, in L'Arca n. 68, pp. 4-II.

Rossi Piero Ostilio (2000). Roma. Guida all'architettura moderna. 1909-2000 (in collaborazione con llaria Gatti). Roma-Bari: Laterza, scheda 195, p. 339.

Villani Paola, (2006). San Valentino. In Stefano Mavilio (a cura di). Guida all'architettura sacra. Roma. 1945-2005. Milano: Electa, pp. $102-10$.

Zoffoli Paolo (1988). Chiesa di San Valentino al Villaggio Olimpico, Roma. In L'industria delle costruzioni, n. 20I-2, a. XXII, pp. $18-25$.

\section{Authors}

Luca Ribichini, Sapienza Università di Roma, luca.ribichini@uniromal.it

Lorenzo Tarquini, Sapienza Università di Roma

Mario Ciamba, Sapienza Università di Roma

Ivan Valcerca, Sapienza Università di Roma

Massimiliano Mastracci, Sapienza Università di Roma

To cite this chapter. Ribichini Luca, Tarquini Lorenzo, Ciamba Mario,Valerca Ivan, Mastracci Massimiliano (2020). Genesi di una forma tra idea, geometria e materia, Francesco Berarducci. Analisi della Chiesa di San Valentino al Villaggio Olimpico/Genesis of a form: idea, geometry and matter Francesco Berarducci. Analysis of the church of St. Valentine, Olympic Village, Rome. In Arena A., Arena M., Brandolino R.G., Colistra D., Ginex G., Mediati D., Nucifora S., Raffa P. (a cura di). Connettere. Un disegno per annodare e tessere. Atti del $42^{\circ}$ Convegno Internazionale dei Docenti delle Discipline della Rappresentazione/Connecting. Drawing for weaving relationships. Proceedings of the 42th International Conference of Representation Disciplines Teachers. Milano: FrancoAngeli, pp. 1385-1410. 